\title{
Reforming the labor market and improving competitiveness: an analysis for Spain using FiMod
}

\author{
Tim Schwarzmüller • Nikolai Stähler
}

Received: 18 November 2011 / Accepted: 5 June 2013 / Published online: 17 July 2013 (C) The Author(s) 2013. This article is published with open access at SpringerLink.com

\begin{abstract}
This paper uses an extended version of "FiMod-A DSGE Model for Fiscal Policy Simulations" (Stähler and Thomas Econ Model 29:239-261, 2012) with endogenous job destruction decisions by private firms to analyze the effects of several currently discussed labor market reforms on the Spanish economy. The main focus is on the firms' hiring and firing decisions, on the implications for fiscal balances and on Spain's international competitiveness. We find that measures aiming at reducing (policy-induced) outside option of workers, such as a decrease in unemployment benefits, public wages or, to a lesser extent, public-sector employment, seem most beneficial to foster output, employment, international competitiveness and fiscal balances. Decreasing the unions' bargaining power also accomplishes this task. Our simulation suggests that reforming employment protection legislation does not seem to be a suitable tool from the perspective of improving international competitiveness. All measures imply (income) redistribution between optimizing and liquidity-constrained consumers. Our analysis also suggests that those reforms that are beneficial for Spain generate positive spillovers to the rest of EMU, too.
\end{abstract}

Keywords General equilibrium - Fiscal policy simulations · Labor market reforms

JEL Classification $\quad \mathrm{E} 24 \cdot \mathrm{E} 32 \cdot \mathrm{E} 62 \cdot \mathrm{H} 20 \cdot \mathrm{H} 50$

\footnotetext{
T. Schwarzmüller

The Kiel Institute for the World Economy, Forecasting Center and Research Area Monetary Policy, Hindenburgufer 66, 24105 Kiel, Germany

e-mail: tim.schwarzmueller@ifw-kiel.de

N. Stähler $(\varangle)$

Economics Department, Deutsche Bundesbank, Wilhelm-Epstein-Str. 14, 60431 Frankfurt, Germany e-mail: nikolai.staehler@bundesbank.de
} 


\section{Introduction}

"The global financial crisis triggered an adjustment in the Spanish real estate sector which had serious consequences for the labor market. Since the beginning of the crisis, more than 2 million jobs have been destroyed (...) raising the unemployment rate above 20\%" (see National Reform Programme Spain 2011, p. 15). ${ }^{1}$ Evidently, the current crisis greatly affected the Spanish labor market. But even in "good times" Spain's unemployment rate was well above the EU average and hardly below around $10 \%$, which hints at some general structural weaknesses. On the labor market, high employment protection and strong unions, among other things, are said by many to have led to disproportionately increasing wage claims, thereby deteriorating Spain's competitiveness vis-á-vis the rest of the monetary union member countries (see, for example, IMF 2011). In order now to tackle these problems, the Spanish government has-after consultation with the European Commission and the International Monetary Fund (IMF) as well as remarkable demonstrations by primarily young citizens in basically any major city — chosen job creation and the reformation of the labor market to become a core goal of economic policy. In this paper, we analyze the short and long-run impact of making the Spanish labor market "more flexible" on output, unemployment, international competitiveness and fiscal balances using an extended version of "FiMod-A DSGE Model for Fiscal Policy Simulations" developed by Banco de España and Deutsche Bundesbank staff for policy simulations. ${ }^{2}$

The present paper has two objectives. First, we evaluate proposed measures to reform the Spanish labor market-more precisely, a permanent cut in employment protection, constantly weakening trade unions as well as a permanent cut in unemployment benefits, public wages and public-sector employment-in a medium-scale dynamic, stochastic, general equilibrium (DSGE) model. Second, more on the technical side, we propose a way how to simultaneously introduce endogenous dismissal decisions by firms and liquidity-constrained consumers in a medium-scale DSGE framework.

DSGE models have recently been more widely used for such analyses as they allow to present arguments in a rather structural way and give some numerical assessment, too. A non-exhaustive overview of papers related to ours are, among others, Zanetti (2011), who finds in a related DSGE model that labor market institutions significantly affect the volatility of output, employment and job flows (negatively for employment protection, positively for unemployment benefits). Thomas and Zanetti (2009) find in a DSGE model with large firms that the effects of such labor market institutions on inflation volatility are rather small. Similarly, Merkl and Schmitz (2011) find that labor market institutions affect inflation volatility to a rather small extent, but they identify significant effects on output volatility. By contrast, Campolmi and Faia (2011) find unemployment benefits to significantly decrease inflation volatility. They, hence,

\footnotetext{
1 Publicly available at the homepage of the Spanish Ministry of Finance and Economics: http://www.meh. es/Documentacion/National\%20Reform\%20Programme\%202011\%20Spain.pdf.

2 The model has been used in the Working Group on Econometric Modelling (WGEM) of the European System of Central Banks (ESCB) to simulate various fiscal consolidation measures for Spain (see Stähler and Thomas 2012).
} 
explain inflation differentials in the euro area by differences in the generosity of the unemployment insurance system. Almeida et al. (2010) address the effects of labor and product market reforms on international competitiveness for Portugal in PESSOA, the DSGE model used by the Portuguese National Bank. A similar analysis can be found in Kilponen and Ripatti (2006) using the Finnish model, in Deák et al. (2011) using the LSM (the Luxembourg Structural Model) and in Krause and Uhlig (2012) analyzing Germany's so-called Hartz IV reforms. These analyses find that, in general, labor market reforms improve competitiveness, foster domestic output and play a part in lowering unemployment. They address labor market reforms only as a cut in the "wage markup" (Almeida et al. 2010; Kilponen and Ripatti 2006) or as a decrease in unemployment benefits (Deák et al. 2011; Krause and Uhlig 2012), however, while we can be somewhat more specific on various measures to be analyzed. Related to this literature, the contribution of the paper at hand is its focus on the effects of specific structural labor market reforms on international competitiveness and fiscal balances.

FiMod, the model we use to analyze these questions, is a two-country monetary union DSGE model with a comprehensive fiscal block that includes a wide range of taxes and quite some disaggregation in government spending. Furthermore, it includes the modern theory of unemployment, extending the model of Stähler and Thomas (2012) by endogenizing job destruction along the lines of Mortensen and Pissarides (1994, 1999, 2003) and Zanetti (2011). Our findings from the model simulations can be summarized as follows.

A decrease in workers' outside option through a decrease in unemployment benefits or public-sector wages and a decrease in union's bargaining power unambiguously decreases private-sector wage claims and makes it more attractive for firms to create jobs. Because of lower labor costs, firms decide to dismiss fewer people, which decreases unemployment. Furthermore, they lower prices. The latter makes Spanish goods cheaper, which fosters exports and improves the terms of trade. Higher production and less unemployment improve fiscal balances. Additionally, they are directly affected by the fact that a cut in the policy-induced expenditure item (unemployment benefits and the public sector wage bill) immediately decreases expenditures. According to our model simulations, these measures have the highest impact on output, employment, international competitiveness and fiscal balances compared to the other measures. In principle, the argumentation also holds for a cut in public employment. However, given that higher private labor demand cannot compensate for the decrease in public employment, unemployment will increase. This, first, diminishes the magnitude of the positive effects resulting from the other two measures just described and, second, may induce firms to dismiss relatively unproductive workers more frequently and to search for more productive ones in the pool of unemployed workers, even though this is costly. As unemployment has increased, search costs may fall to a sufficient extent for such behavior to pay off from the firms' perspective.

Our model simulation suggests that a cut in employment protection is not an adequate measure to tackle problems related to international competitiveness. Indeed, job creation increases as the expected cost of getting rid of a worker falls. However, dismissal probability also increases. On average, workers demand higher wages, 
partly to compensate for the additional dismissal risk, partly because average productivity of employed workers rises due to a rise in the dismissal productivity threshold. Hence, labor costs rise. In order to tackle this, firms increases prices, which deteriorates the terms of trade and causes exports to fall. In our model simulation, unemployment increases as the dismissal effect dominates the job creation effect. The drop in internal and external demand additionally decreases output, contributing to lower labor demand. To put these findings into perspective, some remarks seem in order. First, while reducing average dismissal costs in Spain may-according to our analysis - not contribute to regaining international competitiveness, a reform may still be in order. Spain is characterized by a dual labor market where some benefit greatly from employment protection while others do not have any. Costain et al. (2010) address this issue in a more adequate and very sophisticated model. Also, the comparatively large informal sector may be an issue here. Second, the bargaining game between the union and the firm may have quite an impact on the results. In our model, we follow the standard approach in the matching literature. However, Stähler (2008) has shown that the bargaining game matters. And last but not least, modelling employment protection itself is quite a complicated issue and it probably deserves a more sophisticated modelling than simply implementing firing costs, the approach we followed in the model at hand. For an overview of the different aspects related to employment protection and a discussion, see, among others, Stähler (2007).

The rest of this paper is organized as follows. The model is presented in Sect. 2. Section 3 evaluates the labor market reforms already discussed. We differentiate between short and long-run effects. Section 4 concludes.

\section{The model}

FiMod is a two-country monetary union DSGE model with frictional labor markets and a comprehensive fiscal block that includes a wide range of taxes and disaggregation of government spending. Households, firms, policymakers and the external sector interact each period by trading final goods, financial assets and production factors. In this section we will briefly present the main characteristics of the model and discuss its calibration to make the paper self-contained. Readers who are familiar with FiMod may move on to the labor market section where the endogenous job destruction decision of firms is described. For a complete account of the base model and a more detailed discussion, see Stähler and Thomas (2012).

We start by describing the household sector in Sect. 2.1. Then, we turn to the production sector in Sect. 2.2, while Sect. 2.3 details the labor market. Fiscal authorities are described in Sect. 2.4, followed by a description of international linkages in Sect. 2.5. The calibration strategy is explained in Sect. 2.6.

For what follows, we normalize population size of the monetary union to unity, of which $\omega \in(0,1)$ live in Spain, while the remaining $(1-\omega)$ live in the rest of EMU. Throughout the paper, quantity variables will be expressed in per capita terms, unless otherwise indicated. Both regions are modeled analogously, while we allow structural parameters to differ. 


\subsection{Households}

Following Galí et al. (2007), we assume that each country is populated by a share $(1-\mu)$ of optimizing (or Ricardian) households who have unrestricted access to capital markets and are therefore able to substitute consumption intertemporally. The remaining share $\mu \in[0,1)$ of households is considered to be liquidity-constrained in the sense that they can neither save nor borrow and consume all their labor income in each period. Each household has a continuum of members of size one. The welfare function of each type of representative household at time $t=0$ is given by:

$$
E_{0}\left\{\sum_{t=0}^{\infty} \beta^{t} \cdot u_{t}\left(c_{t}^{i}, c_{t-1}^{i}, \tilde{g}_{t}\right)\right\}
$$

where $E_{t}$ is the expectations operator conditional on time- $t$ information, $c_{t}^{i}$ denotes household consumption of final goods, and the superscripts $i=o, r$ denote optimizing and rule-of-thumb households, respectively. The variable $\tilde{g}_{t}$ is government services produced by public employees, which is taken as given by private households. The instantaneous utility function is given by

$$
u\left(c_{t}^{i}, c_{t-1}^{i}, \tilde{g}_{t}\right)= \begin{cases}\frac{\left[c_{t}^{i}-h \cdot c_{t-1}^{i}\right]^{1-\sigma_{c}}-1}{1-\sigma_{c}}+\zeta \cdot \frac{\tilde{g}_{t}^{1-\sigma_{c}}-1}{1-\sigma_{c}}, & \sigma_{c}>0, \sigma_{c} \neq 1 \\ \log \left[c_{t}^{i}-h \cdot c_{t-1}^{i}\right]+\zeta \cdot \log \left[\tilde{g}_{t}\right], & \sigma_{c}=1\end{cases}
$$

The parameter $\sigma_{c}$ is the coefficient of relative risk aversion, $h$ denotes the degree of habit formation in consumption, and $\zeta>0$ is a parameter capturing the relative valuation of public consumption in the households' utility function.

Inside each household, its members may be employed in the public sector, in the private sector, or unemployed. We assume full consumption insurance within the household, as in Andolfatto (1996) or Merz (1995). This holds both for Ricardian and rule-of-thumb households; see also Boscá et al. $(2009,2010,2011)$ and Stähler and Thomas (2012) for a more detailed discussion.

We assume that both countries trade consumption and investment goods as well as international nominal bonds. The consumption and investment baskets, $c_{t}^{i}$ and $I_{t}^{o}$, respectively, of a household of type $i$ (only type $o$ for investment) in the home country are given by:

$$
x_{t}^{i}=\left(\frac{x_{A t}^{i}}{\omega+\psi}\right)^{\omega+\psi}\left(\frac{x_{B t}^{i}}{1-\omega-\psi}\right)^{1-\omega-\psi}
$$

with $x_{t}^{i}=\left\{c_{t}^{i}, I_{t}^{o}\right\}$, where $c_{A t}^{i}, I_{A t}^{o}$ and $c_{B t}^{i}, I_{B t}^{o}$ represent consumption/investment demand of goods produced in country A (Spain) and B (rest of EMU), respectively, and $\psi$ is a parameter capturing the degree of home bias in consumption. Cost minimization by the household implies 


$$
\frac{x_{A t}^{i}}{x_{B t}^{i}}=\frac{\omega+\psi}{1-\omega-\psi} \frac{P_{B t}}{P_{A t}},
$$

where $P_{A t}$ and $P_{B t}$ are the producer price indexes (PPI) in countries A and B, respectively. From now onwards, let

$$
p_{B t} \equiv \frac{P_{B t}}{P_{A t}}
$$

denote the terms of trade. The above equations imply that nominal expenditure in consumption and investment goods equal $P_{A t} c_{A t}^{i}+P_{B t} c_{B t}^{i}=P_{t} c_{t}^{i}$ and $P_{A t} I_{A t}^{o}+$ $P_{B t} I_{B t}^{o}=P_{t} I_{t}^{o}$, respectively, where

$$
P_{t}=\left(P_{A t}\right)^{\omega+\psi}\left(P_{B t}\right)^{1-\omega-\psi}
$$

is the corresponding consumer price index $(\mathrm{CPI})$. Notice that $P_{t}=P_{A t} \cdot p_{B t}^{1-\omega-\psi}$. Therefore, CPI inflation, $\pi_{t} \equiv P_{t} / P_{t-1}$, evolves according to $\pi_{t}=\pi_{A t}\left(\frac{p_{B t}}{p_{B t-1}}\right)^{1-\omega-\psi}$, where $\pi_{A t} \equiv P_{A t} / P_{A t-1}$ is PPI inflation in country A.

\subsubsection{Optimizing households}

The budget constraint of the representative optimizing households in real terms is

$$
\begin{aligned}
& \left(1+\tau^{c}\right) c_{t}^{o}+I_{t}^{o}+\frac{B_{t}^{o}+D_{t}^{o}}{P_{t}}+\frac{T_{t}}{1-\mu}=\frac{\Pi_{t}}{P_{t}}+\left(\left(1-\tau^{k}\right) r_{t}^{k}+\tau^{k} \delta^{k}\right) k_{t-1}^{o} \\
& +\frac{R_{t-1} B_{t-1}^{o}}{P_{t}}+\frac{R_{t-1}^{e c b} e^{-\psi_{d}\left(d_{t-1}-\bar{d}\right) / Y_{t-1}} D_{t-1}^{o}}{P_{t}} \\
& \quad-\tau^{b} \frac{\left(R_{t-1}-1\right) B_{t-1}^{o}}{P_{t}}+\frac{S u b_{t}}{1-\mu} \\
& \quad+\left(1-\tau^{w}\right)\left(w_{t}^{p} n_{t}^{p, o}+w_{t}^{g} n_{t}^{g, o}\right)+\left(1-n_{t}^{p, o}-n_{t}^{g, o}\right) \kappa^{B}
\end{aligned}
$$

Each optimizing household's real labor income (gross of taxes) is given by $w_{t}^{p} n_{t}^{p, o}+$ $w_{t}^{g} n_{t}^{g, o}$, where $w_{t}^{p}$ is the real wage paid in the private sector (to be derived later), $w_{t}^{g}$ is the real wage of the government sector, and $n_{t}^{p, o}$ and $n_{t}^{g, o}$ are the number of type- $o$ household members employed in the private and government sector, respectively. The labor income tax rate is denoted by $\tau^{w}$. Unemployed household members receive unemployment benefits $\kappa^{B}$. $\tau^{c}$ denotes the consumption tax rate. Investments in physical capital $k_{t}^{o}$ earn a real rental rate $r_{t}^{k}$, while the capital depreciates at rate $\delta^{k}$. Returns on physical capital net of depreciation allowances are taxed at rate $\tau^{k}$. The optimizing household can also purchase nominal government bonds $B_{t}^{o}$, which pay a gross nominal interest rate $R_{t}$. Returns on government bonds are taxed at the rate $\tau^{b}$. Finally, optimizing households can hold international nominal bonds, $D_{t}^{o}$. In order to ensure stationarity of equilibrium, we follow Schmitt-Grohé and Uribe (2003) and assume that home agents pay a risk premium on top of the area-wide nominal policy 
rate, which we denote by $R_{t}^{e c b}$. This implies that the nominal interest rate paid or received by home investors is given by $R_{t}^{e c b} \exp \left(-\psi_{d}\left(d_{t}-\bar{d}\right) / Y_{t}\right)$, with $\psi_{d}>0$, where $d_{t} \equiv D_{t} / P_{A t}, D_{t}$ is the home country's nominal net foreign asset position and $(-) d_{t} / Y_{t}$ is the ratio of net foreign debt over output. We assume for simplicity that trading in international bonds is not taxed. ${ }^{3} \Pi_{t}$ are nominal per capita profits generated by firms including vacancy posting costs. We assume that all firms are owned by the optimizing households and that profits are redistributed in a lump-sum manner. $T_{t}$ and $S u b_{t}$ are lump-sum taxes and subsidies, respectively.

The law of motion of private physical capital is given by:

$$
k_{t}^{o}=\left(1-\delta^{k}\right) k_{t-1}^{o}+\left[1-S\left(I_{t}^{o} / I_{t-1}^{o}\right)\right] I_{t}^{o},
$$

where $S\left(I_{t}^{o} / I_{t-1}^{o}\right)=\frac{\kappa_{I}}{2}\left(I_{t}^{o} / I_{t-1}^{o}-1\right)^{2}$ represents investment adjustment costs (see Christiano et al. 2005, for discussion). Maximizing (1) given (2) subject to Eqs. (3) and (4) yields the following standard first-order conditions,

$$
\begin{aligned}
& \text { for } c_{t}^{o}: \lambda_{t}^{o}=\frac{\left[c_{t}^{o}-h \cdot c_{t-1}^{o}\right]^{-\sigma_{c}}-\beta \cdot h \cdot E_{t}\left\{\left[c_{t+1}^{o}-h \cdot c_{t}^{o}\right]^{-\sigma_{c}}\right\}}{\left(1+\tau^{c}\right)}, \\
& \text { for } B_{t}^{o}: \lambda_{t}^{o}=\beta \cdot E_{t}\left\{\lambda_{t+1}^{o} \cdot \frac{R_{t} \cdot\left(1-\tau^{b}\right)+\tau^{b}}{\pi_{t+1}}\right\}, \\
& \text { for } k_{t}^{o}: \quad Q_{t}=\beta \cdot E_{t}\left\{\frac{\lambda_{t+1}^{o}}{\lambda_{t}^{o}}\left[\left(1-\delta^{k}\right) Q_{t+1}+\left(1-\tau^{k}\right) \cdot r_{t+1}^{k}+\tau^{k} \cdot \delta^{k}\right]\right\}, \\
& \text { for } I_{t}^{o}: \quad 1= Q_{t}\left[1-S\left(I_{t}^{o} / I_{t-1}^{o}\right)-I_{t}^{o} \cdot S^{\prime}\left(I_{t}^{o} / I_{t-1}^{o}\right)\right] \\
&+\beta \cdot E_{t}\left\{\frac{\lambda_{t+1}^{o}}{\lambda_{t}^{o}} Q_{t+1} \frac{I_{t+1}^{o}{ }^{2}}{I_{t}^{o}} S^{\prime}\left(I_{t+1}^{o} / I_{t}^{o}\right)\right\}, \\
& \text { for } D_{t}^{o}: \quad \lambda_{t}^{o}= \beta R_{t}^{e c b} \cdot e^{-\psi_{2}\left(d_{t}-\bar{d}\right) / Y_{t}} \cdot E_{t}\left\{\frac{\lambda_{t+1}^{o}}{\pi_{t+1}}\right\},
\end{aligned}
$$

where $\lambda_{t}^{o}$ is the Lagrange multiplier on Eq. (3) and $Q_{t} \cdot \lambda_{t}^{o}$ is the Lagrange multiplier on Eq. (4). Therefore, $\lambda_{t}^{o}$ represents the marginal utility of real income, whereas $Q_{t}$ represents the shadow real price of a unit of physical capital, i.e. Tobin's $Q$. We also assume that the No-Ponzi condition on wealth is satisfied.

\subsubsection{Non-Ricardian households}

As non-Ricardian households can neither save nor borrow, their budget constraint simplifies to

$$
\left(1+\tau^{c}\right) c_{t}^{r}=\left(1-\tau^{w}\right)\left(w_{t}^{p} n_{t}^{p, r}+w_{t}^{g} n_{t}^{g, r}\right)+\left(1-n_{t}^{p, r}-n_{t}^{g, r}\right) \kappa^{B},
$$

\footnotetext{
3 Note also that this modelling strategy generates some sort of iceberg costs because the indebted country pays a higher interest rate than the one the debtor country receives. However, this (non-microfounded) way of modelling is common modelling practice in international macroeconomics.
} 
which determines rule-of-thumb consumption, $c_{t}^{r}$. The corresponding marginal utility of consumption for rule-of-thumb households is thus

$$
\lambda_{t}^{r}=\frac{\left[c_{t}^{r}-h \cdot c_{t-1}^{r}\right]^{-\sigma_{c}}-\beta \cdot h \cdot E_{t}\left\{\left[c_{t+1}^{r}-h \cdot c_{t}^{r}\right]^{-\sigma_{c}}\right\}}{\left(1+\tau^{c}\right)} .
$$

Note that RoT households are not taxed lump-sum. The reason for this is that, in what follows, we are interested in the isolated effects of the labor market reforms discussed below, and we want to avoid introducing additional distortions stemming from the fiscal side. If we taxed RoTs, too, this would imply a change in their consumption behavior, their discounting and, hence, would therefore affect the labor market as we will see below. Therefore, we introduce this entirely non-distortionary lump-sum tax levied on optimizers as a theoretical construct to highlight the fiscal leeway (or shortage) resulting from the structural labor market reforms discussed below; see also Sect. 2.4.

\subsubsection{Aggregation}

Given the above description, consumption per capita in the home country equals the weighted average of consumption for each household type, i.e.

$$
C_{t}=(1-\mu) \cdot c_{t}^{o}+\mu \cdot c_{t}^{r}
$$

For future reference, per capita domestic demand for the home country's and the foreign country's consumption good equals $C_{A t}=(1-\mu) c_{A t}^{o}+\mu c_{A t}^{r}$ and $C_{B t}=$ $(1-\mu) c_{B t}^{o}+\mu c_{B t}^{r}$, respectively. For the quantity variables that exclusively concern optimizing households, per capita amounts are given simply by $Z_{t}=(1-\mu) Z_{t}^{o}$, where $Z_{t} \in\left\{k_{t}, B_{t} / P_{t}, I_{t}, D_{t}, I_{A t}, I_{B t}\right\}$ and $Z_{t}^{o} \in\left\{k_{t}^{o}, B_{t}^{o} / P_{t}, I_{t}^{o}, D_{t}^{o}, I_{A t}^{o}, I_{B t}^{o}\right\}$. Employment aggregation will be described in the labor market section.

\subsection{Production}

The retail and intermediate goods sectors of the economy are similar to Smets and Wouters $(2003,2007)$ or Christiano et al. (2005), with the exception that labor services are not hired directly from the households but from a sector of firms that produce homogenous labor services in the manner of Christoffel et al. (2009) or DeWalque et al. (2009). It is the latter firms that hire workers and bargain over wages with them. In this subsection, we focus on the retail and intermediate goods sectors, postponing the description of the labor market to the next subsection.

\subsubsection{Retailers}

There is a measure- $\omega$ continuum of firms in the retail (or final goods) sector. Each retail firm purchases a variety of differentiated intermediate goods, bundles these into a final good and sells the latter under perfect competition. We assume that the law of 
one price holds within the union, which means that the price of the home country's final good is the same in both countries and equal to $P_{A t}$. The maximization problem of the representative retail firm reads

$$
\max _{\left\{\tilde{y}_{t}(j): j \in[0, \omega]\right\}} P_{A t} Y_{t}-\int_{0}^{\omega} P_{A t}(j) \tilde{y}_{t}(j) d j,
$$

where

$$
Y_{t}=\left(\int_{0}^{\omega}\left(\frac{1}{\omega}\right)^{1 / \epsilon} \tilde{y}_{t}(j)^{(\epsilon-1) / \epsilon} d j\right)^{\epsilon /(\epsilon-1)}, \quad \epsilon>1,
$$

is the retailer's production function, $\tilde{y}_{t}(j)$ is the retailer's demand for each differentiated input $j \in[0, \omega]$, and $P_{A t}(j)$ is the nominal price of each input. The first-order condition for each input $j \in[0, \omega] \operatorname{reads} \tilde{y}_{t}(j)=\left(\frac{P_{A t}(j)}{P_{A t}}\right)^{-\epsilon} \frac{Y_{t}}{\omega}$. Combining the latter with (13) and the zero profit condition, we obtain that the producer price index in the home country must equal $P_{A t}=\left(\int_{0}^{\omega} \frac{1}{\omega} P_{A t}(j)^{1-\epsilon} d j\right)^{1 /(1-\epsilon)}$. Notice that, since there are $\omega$ retail firms, total demand for each intermediate input equals

$$
\omega \tilde{y}_{t}(j) \equiv y_{t}(j)=\left(\frac{P_{A t}(j)}{P_{A t}}\right)^{-\epsilon} Y_{t} .
$$

\subsubsection{Intermediate goods}

Firms in the intermediate goods sector have mass $\omega$. Each producer $j \in[0, \omega]$ operates the following technology:

$$
y_{t}(j)=\epsilon^{a} \cdot\left(k_{t-1}^{g}\right)^{\eta} \cdot\left[\tilde{k}_{t}(j)\right]^{\alpha} \cdot\left[l_{t}(j)\right]^{(1-\alpha)},
$$

where $\alpha \in[0,1]$ is the elasticity of output with respect to private capital, $l_{t}(j)$ denotes the demand for labor services, $\tilde{k}_{t}(j)$ is the demand for capital services and $\epsilon^{a}$ is TFP. $k_{t-1}^{g}$ is the public capital stock available in period $t$, which is determined by the government and is assumed to be productivity-enhancing; the parameter $\eta \in[0,1)$ measures how influential public capital is on private production (see Leeper et al. 2010, for discussion). Intermediate goods firms acquire labor and capital services in perfectly competitive factor markets at real (CPI-deflated) prices $x_{t}$ and $r_{t}^{k}$, respectively. In period $t$, the real profits of firm $j$ are thus given by $\frac{P_{A t}(j)}{P_{t}} y_{t}(j)-x_{t} \cdot l_{t}(j)-r_{t}^{k} \cdot \tilde{k}_{t}(j)$. Cost minimization subject to (16) implies the following factor demand conditions:

$$
\begin{aligned}
& r_{t}^{k}=m c_{t} \cdot \alpha \cdot \frac{y_{t}(j)}{\tilde{k}_{t}(j)}, \\
& x_{t}=m c_{t} \cdot(1-\alpha) \cdot \frac{y_{t}(j)}{l_{t}(j)},
\end{aligned}
$$


where $m c_{t}$ is the real (CPI-deflated) marginal cost common to all intermediate good producers. Recall that constant returns to scale in private capital and labor, together with perfectly competitive input prices, imply that the ratios $y_{t}(j) / \tilde{k}_{t}(j)$ and $y_{t}(j) / l_{t}(j)$ are equalized across firms.

We assume that intermediate goods firms set nominal prices á la Calvo (1983). Each period, a randomly chosen fraction $\theta_{P} \in[0,1)$ of firms cannot re-optimize their price. A firm that has the chance to re-optimize its price in period $t$ chooses the nominal price $P_{A t}(j)$ that maximizes

$$
E_{t} \sum_{z=0}^{\infty}\left(\beta \theta_{P}\right)^{z} \frac{\lambda_{t+z}^{o}}{\lambda_{t}^{o}}\left[\frac{P_{A t}(j)}{P_{t+z}}-m c_{t+z}\right] y_{t+z}(j)
$$

subject to $y_{t+z}(j)=\left(P_{A t}(j) / P_{A t+z}\right)^{-\epsilon} Y_{t+z}$. The first-order condition is given by:

$$
E_{t} \sum_{z=0}^{\infty}\left(\beta \theta_{P}\right)^{z} \frac{\lambda_{t+z}^{o}}{\lambda_{t}^{o}}\left[\frac{\tilde{P}_{A t}}{P_{t+z}}-\frac{\epsilon}{\epsilon-1} m c_{t+z}\right]\left(\frac{\tilde{P}_{A t}}{P_{A t+z}}\right)^{-\epsilon} Y_{t+z}=0
$$

where $\tilde{P}_{A t}$ is the optimal price chosen by all period- $t$ price setters. The law of motion of the price level is then given by:

$$
1=\theta_{P}\left(\frac{1}{\pi_{A t}}\right)^{1-\epsilon}+\left(1-\theta_{P}\right) \tilde{p}_{t}^{1-\epsilon}
$$

where $\tilde{p}_{t} \equiv \tilde{P}_{A t} / P_{A t}$ is the relative (PPI-deflated) optimal price.

\subsection{The labor market}

Labor firms hire and fire workers from the household sector in order to produce homogenous labor services, which they sell to intermediate goods producers at the perfectly competitive price $x_{t}$. This modelling strategy follows Christoffel et al. (2009). We follow Zanetti (2011) to endogenize (private-sector) dismissals by including idiosyncratic job-specific productivity shocks. Following the exposition of Pissarides (2000), surplus calculations are carried out on a per-worker basis. The production function of each labor firm is linear in average idiosyncratic productivity by its employees, which is given by $h_{t}^{a v}$ and will be determined later in Sect. 2.3.2. Letting $N_{t}^{p}$ denote both the fraction of the labor force employed in the private sector and the per-capita number of labor firms, the total per-capita supply of labor services is given by:

$$
L_{t}=N_{t}^{P} \cdot h_{t}^{a v}
$$

Equilibrium in the market for labor services requires that $\omega L_{t}=\int_{0}^{\omega} l_{t}(j) d j$. Using Eqs. (15) and (16), together with the fact that the capital-labor ratio is equalized across intermediate goods firms (i.e. $\tilde{k}_{t}(j) / l_{t}(j)=k_{t-1} / L_{t}$ for all $j$ ), the above condition can 
be expressed as $Y_{t} D_{t}=\epsilon^{a}\left(k_{t-1}^{g}\right)^{\eta} k_{t-1}^{\alpha} L_{t}^{1-\alpha}$, where $D_{t} \equiv \int_{0}^{\omega} \omega^{-1}\left(P_{A t}(j) / P_{A t}\right)^{-\epsilon} d j$ is a measure of price dispersion. In what follows, we will specify the matching process and flows in the labor market, vacancy creation and job destruction as well as (private) wage determination. Government wages and employment are autonomously chosen by the fiscal authority (see Sect. 2.4).

\subsubsection{Matching and dismissal processes and labor market flows}

A worker can be in one of three states: (i) unemployed, (ii) employed in the public sector, or (iii) employed in the private sector. Unemployment is the residual state in the sense that a worker whose employment relationship ends flows back into unemployment. Unemployed workers look for job opportunities. They find them either in the public sector (with superscript $g$ for government employment) or in the private sector (with superscript $p$ ). Workers do not direct search to either the public or the private sector and are, thus, matched randomly.

Let us denote sector-specific per capita employment in period $t$ by $N_{t}^{f}$, where $f=p, g$ stands for private and public (i.e. government) employment, respectively. ${ }^{4}$ The total employment rate is then given by $N_{t}^{t o t}=N_{t}^{p}+N_{t}^{g}$, while the unemployment rate is given by:

$$
U_{t}=1-N_{t}^{t o t}
$$

Following Blanchard and Galí (2010), we assume that the hiring round takes place at the beginning of each period, and that new hires start producing immediately. We also assume that workers dismissed at the end of period $t-1$ start searching for a new job at the beginning of period $t$. Therefore, the pool of searching workers at the beginning of period $t$ is given by:

$$
\tilde{U}_{t}=U_{t-1}+s_{t}^{p} N_{t-1}^{p}+s^{g} N_{t-1}^{g},
$$

where $s^{g}$ represents the constant separation rate in the public sector. The separation rate in the private sector, $s_{t}^{p}$, is time-varying as it depends on the dismissal decision of firms. We will describe this in more detail in a moment.

The matching process is governed by a standard Cobb-Douglas aggregate matching function for each sector $f=p, g$,

$$
M_{t}^{f}=\kappa_{e}^{f} \cdot\left(\tilde{U}_{t}\right)^{\varphi^{f}} \cdot\left(v_{t}^{f}\right)^{\left(1-\varphi^{f}\right)},
$$

\footnotetext{
4 Note that, as we work with household type-specific (un)employment rates for each sector in the households' budget constraints (see Eqs. (3) and (10), we basically have to aggregate employment in order to obtain total (per capita) employment levels across public and private employment. This is done in analogy to the aggregation of consumption decisions see Sect. 2.1.3; again implying that capital letters indicate aggregate levels). Thus, aggregated per capita employment levels in each sector are given by $N_{t}^{f}=(1-\mu) \cdot n_{t}^{f, o}+\mu \cdot n_{t}^{f, r}$. Noting that dismissal and job-finding probabilities are equal across household types, we have that $N_{t}^{f}=n_{t}^{f, o}=n_{t}^{f, r}$; see also Moyen and Stähler (2013) for details.
} 
where $\kappa_{e}^{f}>0$ is the sector-specific matching efficiency parameter, $\varphi^{f} \in(0,1)$ the sector-specific matching elasticity and $M_{t}^{f}$ the number of new matches formed in period $t$ resulting from the total number of searchers and the number of sector-specific vacancies $v_{t}^{f}$. Note that, by allowing for the possibility that $\varphi^{p} \neq \varphi^{g}$, the matching process in the public and private sector may differ. The probability for an unemployed worker to find a job in sector $f$ can thus be stated as $p_{t}^{f}=M_{t}^{f} / \tilde{U}_{t}$, while the probability of filling a vacancy is given by $q_{t}^{f}=M_{t}^{f} / v_{t}^{f}$.

During each period $t$, the flow into unemployment from the private sector results from an exogenous shock, $s^{x}$, and from a shock to the idiosyncratic productivity of active jobs, $h_{t}$, leading to an endogenous job destruction probability $s_{t}^{n}=F\left(\tilde{h}_{t}\right)$ when idiosyncratic productivity of an active job falls below some endogenously determined threshold, $\tilde{h}_{t}$. The exogenous separation probability $s^{x}$ —as well as the corresponding probability in the public sector, $s^{g}$ —can be interpreted as an exogenous retirement rate (see, for example, Costain et al. 2010). As described in Mortensen and Pissarides (1994, 1999, 2003), we assume that new matches are always endowed with a productivity $h^{\text {new }}>\tilde{h}_{t}$ and, thus, that newly created jobs never separate for endogenous reasons in the period they are created. Total private job separations are, hence, given by $s_{t}^{p}=$ $s^{x}+\left(1-s^{x}\right) s_{t}^{n}$. As is standard in the literature, we assume that the idiosyncratic productivity shock will be $\log$-normally distributed with $\log \left(h_{t}\right) \sim N\left(\mu_{h}, \sigma_{h}\right)$.

The law of motion for sector-specific employment rates is therefore given by:

$$
N_{t}^{g}=\left(1-s^{g}\right) \cdot N_{t-1}^{g}+p_{t}^{g} \cdot \tilde{U}_{t} \quad \text { and } \quad N_{t}^{p}=\left(1-s_{t}^{p}\right) \cdot N_{t-1}^{p}+p_{t}^{p} \cdot \tilde{U}_{t}
$$

for the public $\left(g\right.$ ) and the private $(p)$ sector, respectively. ${ }^{5}$ Thus, sector-specific employment today is given by yesterday's employment that has not been destroyed plus newly created matches in that sector. For simplification, we assume that workers do not receive offers from the public and the private sector simultaneously.

\subsubsection{Asset value of jobs and wage bargaining}

Because of search frictions, formed matches entail economic rents. A union bargains with firms about the workers' share of the overall match surplus. We assume that there exists a median voter union which sets one wage, $w_{t}^{p}$, common for all workers in the private sector. We detail the union below. In order to describe the bargaining process, we first have to derive the asset value functions for workers and firms. The present-discounted value of a firm hiring a newly matched worker can be expressed as:

$$
\begin{aligned}
J_{t}\left(h_{t}\right)= & x_{t} \cdot h_{t}-\left(1+\tau^{s c}\right) w_{t}\left(h_{t}\right)+\beta\left(1-s^{x}\right) E_{t} \\
& \times\left\{\frac{\lambda_{t+1}^{o}}{\lambda_{t}^{o}}\left[\int_{\tilde{h}_{t+1}}^{\infty} J_{t+1}\left(h_{t+1}\right) d F\left(h_{t+1}\right)-F\left(\tilde{h}_{t+1}\right) \kappa^{F}\right]\right\} .
\end{aligned}
$$

\footnotetext{
5 Remember that private-sector job destruction is time-varying because of endogenous job destruction, while public-sector job destruction is exogenously given.
} 
where $x_{t}$ is the price the labor-goods firm charges for providing the labor service and $h_{t}$ is the (productivity-weighted) "amount" of labor service provided by the labor firm. It has to pay a wage $w_{t}^{p}$ to the worker plus social security contributions to the state at rate $\tau^{s c}$. Whenever the job is not destroyed next period at exogenous probability, $s^{x}$, a new idiosyncratic productivity is drawn from the distribution function $F\left(h_{t}\right)$. If this productivity is above the endogenously determined threshold value $\tilde{h}_{t+1}$, the firm earns the present-discounted value of a continuing job with the corresponding productivity, i.e. $J_{t+1}\left(h_{t+1}\right)$. Whenever the productivity falls below the threshold, which happens at (expected) probability $F\left(\tilde{h}_{t+1}\right)$, it has to pay a dismissal tax $\kappa^{F}$. Hence, a job yields a net return $x_{t} h_{t}-\left(1+\tau^{s c}\right) w_{t}^{p}$ plus an expected present-discounted net value $J_{t+1}\left(h_{t+1}\right)-F\left(\tilde{h}_{t+1}\right) \kappa^{F}$ in the following period. Note that firms use the marginal utility of optimizing households, $\lambda_{t}^{o}$, to discount future periods as we assume that firms are owned by optimizers.

Opening a vacancy has a real (CPI-deflated) flow cost of $\kappa_{v}^{p}$. Free entry into the vacancy posting market drives the expected value of a vacancy to zero (see Pissarides 2000). Under our assumption of instantaneous hiring, real vacancy posting costs, $\kappa_{v}^{p}$, must equal the time- $t$ vacancy filling probability, $q_{t}^{p}$, times the expected value of a filled job in period $t$. The latter condition can be expressed as:

$$
\frac{\kappa_{v}^{p}}{q_{t}^{p}}=J_{t}^{n e w}
$$

We can now derive the asset value functions of workers. In particular, we are interested in the value of the job in excess of the value of being unemployed, i.e. the worker's match surplus. Since different household types use different stochastic discount factors, we must distinguish between the surplus for an optimizing and a rule-of-thumb household. For a worker belonging to a type- $i$ household, the surplus value of being employed in a continuing job in the private sector is given by:

$$
\begin{aligned}
H_{t}^{i, p}= & \left(1-\tau^{w}\right) w_{t}^{p}-\kappa^{B}+\beta\left(1-s^{x}\right) E_{t} \\
& \times\left\{\frac{\lambda_{t+1}^{i}}{\lambda_{t}^{i}}\left[\left(1-F\left(\tilde{h}_{t+1}\right)-p_{t+1}^{p}\right) H_{t+1}^{i, p}-p_{t+1}^{g} H^{i, g}\right]\right\}
\end{aligned}
$$

for $i=o, r$ (remember that there is a common private-sector wage $w_{t}^{p}$ independent of the worker's individual productivity or type). The value of being employed in the public sector can be stated as:

$$
H_{t}^{i, g}=\left(1-\tau^{w}\right) w_{t}^{g}-\kappa^{B}+\beta\left(1-s^{g}\right) E_{t}\left\{\frac{\lambda_{t+1}^{i}}{\lambda_{t}^{i}}\left[\left(1-p_{t+1}^{g}\right) H_{t+1}^{i, g}-p_{t+1}^{p} H^{i, p}\right]\right\} .
$$

Hence, an employed worker receives a wage depending on which sector (private or public) he works in. Additionally, he receives the option value of the job in case it continues in the next period. The outside option of the worker-i.e. his forgone income 
of being unemployed-is the sum of unemployment benefits, $\kappa^{B}$, and the expected value of searching for a job in the following period, where $p_{t+1}^{f}$ is the probability of finding a job in sector $f=g, p$. Conditional on landing on a private-sector job, the surplus of the worker is the surplus of being newly employed in the private sector; when landing on a public-sector job, it is the surplus of working in the public sector. For an unemployed worker to be willing to work, it must always hold that $H_{t}^{i, f}>0$. In the private sector, this always holds because of the bargaining game, while calibration guarantees this to hold in the public sector, too.

As in Stähler and Thomas (2012), who follow Boscá et al. (2009, 2010, 2011), private-sector wage bargaining is modelled as a Nash-bargaining game between a union and the firm. We assume that the union imposes a perfectly egalitarian wage among its members. Given that all workers are union member, we assume that the wage is set through the median-voter theorem and is, hence, determined by the median worker's productivity level $h^{\text {med }}$. Formally, the union's utility can be represented by $\Omega_{t} \equiv(1-\mu) H_{t}^{o, p}+\mu H_{t}^{r, p}$. In the bargaining process, we have to take into account that the median worker is an employed worker. Hence, in case of disagreement, firms in will have to pay the dismissal tax, $\kappa^{F}$. The maximization problem is, therefore, $\max _{w_{t}^{p}}\left[\Omega_{t}\right]^{\xi}\left[J_{t}\left(h^{\text {med }}\right)+\kappa^{F}\right]^{1-\xi}$. The resulting sharing rule is given by:

$$
\Omega_{t}=\frac{\xi}{1-\xi} \cdot \frac{1-\tau^{w}}{1+\tau^{s c}} \cdot\left[J_{t}\left(h^{m e d}\right)+\kappa^{F}\right]
$$

Solving Eq. (30) for the corresponding wage by using the appropriate firm and worker asset value functions as well as Eqs. (30) and (27) gives:

$$
w_{t}^{p}=\xi \cdot\left[\frac{x_{t} \cdot h^{m e d}}{1+\tau^{s c}}+\left(1-\beta\left(1-s^{x}\right) E_{t}\left\{\frac{\lambda_{t+1}^{o}}{\lambda_{t}^{o}}\right\}\right) \frac{\kappa^{F}}{1+\tau^{s c}}\right]+(1-\xi) \frac{\kappa^{B}}{1-\tau^{w}}+\Xi_{t},
$$

where

$$
\begin{aligned}
\Xi_{t}=\beta\left(1-s^{x}\right) E_{t}\left\{\frac { \lambda _ { t + 1 } ^ { o } } { \lambda _ { t } ^ { o } } \left[\xi \cdot x_{t+1} \cdot \frac{\int_{\tilde{h}_{t+1}}^{\infty}\left[h_{t+1}-\tilde{h}_{t+1}\right] d F\left(h_{t+1}\right)+p_{t+1}^{p}\left[h^{\text {med }}-\tilde{h}_{t+1}\right]}{\left(1+\tau^{s c}\right)}\right.\right. \\
\left.+p_{t+1}^{g} \frac{(1-\xi)}{\left(1-\tau^{w}\right)} \cdot \Omega_{t+1}^{g}\right]+\mu\left(\frac{\lambda_{t+1}^{o}}{\lambda_{t}^{o}}-\frac{\lambda_{t+1}^{r}}{\lambda_{t}^{r}}\right) \\
\left.\times\left[\left(1-F\left(\tilde{h}_{t+1}\right)-p_{t+1}^{p}\right) H_{t+1}^{r, p}-p_{t+1}^{g} H_{t+1}^{r, g}\right]\right\}
\end{aligned}
$$

is the expected future option value of the union. It includes the expected value of being matched to a private or public job in the next period for unemployed workers and a "union/Rot-smoothing" term (last term of the equation). ${ }^{6}$ The latter reminds us that

$\overline{{ }^{6} \text { Note that } \Omega_{t}^{g}=(1-\mu) H_{t}^{o, g}}+\mu H_{t}^{r, g}$. 
there is risk sharing at the household level, but not between households. Although optimizing and RoT households may have a different reservation wage, they pool together in the labor market via the union structure and bargain with firms to distribute employment according to their share in the population. This implies that all household types receive the same wage and suffer the same unemployment rate. In contrast to Galí et al. (2007), this means that although RoT consumers cannot use wealth for consumption smoothing over time, they take advantage of the fact that a match today is likely to continue in the future, yielding a labor income that will be used to consume tomorrow. Therefore, unionized wage negotiations provide RoT consumers the opportunity to improve their lifetime utility by narrowing the gap in utility with respect to optimizing consumers (see also Boscá et al. 2010, 2011, for more details). Note that this "union/Rot-smoothing" term is zero in steady state.

\subsubsection{Job creation and job destruction conditions}

As we have already noted in Eq. (27), vacancies are created as long as the value of a newly created job equals average search costs. By substituting the above asset value functions and wages and rearranging, we obtain

$$
\left[x_{t} \cdot\left(h^{n e w}-\tilde{h}_{t}\right)-\kappa^{F}\right]=\frac{\kappa^{v}}{q_{t}}
$$

as the job creation condition (JC henceforth). Because, in equilibrium, jobs are destroyed when the surplus the labor firm receives from the job falls below dismissal costs, we note that the job destruction condition (JD henceforth) can be expressed as $J_{t}\left(\tilde{h}_{t}\right)=-\kappa^{F}$. Substitution of wages and rearranging yields

$$
\begin{gathered}
x_{t} \cdot\left(\tilde{h}_{t}-\zeta \cdot h^{m e d}\right)-(1-\zeta) \frac{1+\tau^{s c}}{1-\tau^{w}} \kappa^{B}+\left(1-\beta\left(1-s^{x}\right) E_{t}\left\{\frac{\lambda_{t+1}^{o}}{\lambda_{t}^{o}}\right\}\right)(1-\zeta) \kappa^{F} \\
+\beta\left(1-s^{x}\right) E_{t}\left\{\frac{\lambda_{t+1}^{o}}{\lambda_{t}^{o}} x_{t+1} \int_{\tilde{h}_{t+1}}^{\infty}\left(h_{t+1}-\tilde{h}_{t+1}\right) d F\left(h_{t+1}\right)\right\}-\left(1+\tau^{s c}\right) \cdot \Xi_{t}=0 .
\end{gathered}
$$

As Zanetti (2011) has shown, the weight for continuing jobs is given by $\omega_{t}^{c}=$ $\left(1-s_{t}^{p}\right) \frac{N_{t-1}^{p}}{N_{t}^{p}}$, while that for newly created jobs is given by $\left(1-\omega_{t}^{c}\right)$. The average idiosyncratic private-sector productivity, therefore, is $h_{t}^{a v}=\omega_{t}^{c} \cdot \int_{\tilde{h}_{t}}^{\infty} \frac{h f(h)}{1-F\left(\tilde{h}_{t}\right)} d h+(1-$ $\left.\omega_{t}^{c}\right) h^{\text {new }}$, which we have also used in Eq. (22). Note that the integral term is average productivity of continuing jobs. 


\subsection{Fiscal authorities}

The real (CPI-deflated) per capita value of end-of-period government debt, $b_{t} \equiv$ $B_{t} / P_{t}$, evolves according to a standard debt accumulation equation,

$$
b_{t}=\frac{R_{t-1}}{\pi_{t}} b_{t-1}+P D_{t}
$$

where $P D_{t}$ denotes real (CPI-deflated) per capita primary deficit. The latter is given by per capita fiscal expenditures minus per capita fiscal revenues,

$$
\begin{aligned}
P D_{t}= & {\left[\frac{G_{t}}{p_{B t}^{1-\omega-\psi}}+\kappa^{B} U_{t}+\kappa_{v}^{g} \cdot v_{t}^{g}+S u b_{t}\right] } \\
& -\left[\left(\tau^{w}+\tau^{s c}\right)\left[w_{t}^{p} N_{t}^{P}+w_{t}^{g} N_{t}^{g}\right]+\tau^{b} \frac{R_{t-1}-1}{\pi_{t}} b_{t-1}\right. \\
& \left.+\tau^{c} C_{t}+\tau^{k}\left(r_{t}^{k}-\delta^{k}\right) k_{t-1}+T_{t}+\left(1-s^{x}\right) \cdot s_{t}^{n} \cdot N_{t}^{P} \cdot \kappa^{F}\right],
\end{aligned}
$$

where $G_{t}$ denotes per capita government spending in goods and services expressed in PPI terms (hence the correction for the CPI-to-PPI ratio, $P_{t} / P_{A t}=p_{B t}^{1-\omega-\psi}$ ) and $\kappa_{v}^{g}$ are public-sector vacancy costs. Government spending in goods and services is in turn the sum of government demand for privately-produced consumption and investment goods and the public sector wage bill (gross of social security contributions). Following standard practice, we assume full home bias in public purchases and public investment, such that their nominal price is equal to the home country PPI, $P_{A t}$. Letting $C_{t}^{g}$ and $I_{t}^{g}$ denote real per capita public purchases and public investment, respectively, we have the following nominal relationship: $P_{A t} G_{t}=P_{A t}\left(C_{t}^{g}+I_{t}^{g}\right)+\left(1+\tau^{s c}\right) P_{t} w_{t}^{g} N_{t}^{g}$. Dividing by $P_{A t}$ and using $P_{t} / P_{A t}=p_{B t}^{1-\omega-\psi}$, we obtain

$$
G_{t}=C_{t}^{g}+I_{t}^{g}+\left[\left(1+\tau^{s c}\right) w_{t}^{g} N_{t}^{g}\right] p_{B t}^{1-\omega-\psi} .
$$

Note furthermore that we assume for simplicity that firing costs revert to the government, which is perfectly standard in the literature (see, for example, Thomas and Zanetti 2009). Given public investment, the stock of public physical capital evolves as follows:

$$
k_{t}^{g}=\left(1-\delta^{g}\right) k_{t-1}^{g}+I_{t}^{g},
$$

where we assume that the public capital stock depreciates at rate $\delta^{g}$.

Given that we treat tax rates as constant, the government has one fiscal instrument on the revenue side: lump-sum taxes, $T_{t}$. It has five instruments on the expenditures side: public purchases, $C_{t}^{g}$, public investment, $I_{t}^{g}$, public sector wages, $w_{t}^{g}$, public employment, $N_{t}^{g}$, and lump-sum subsidies, $S u b_{t}$. In order to guarantee stability, at least one instrument must react to the debt-to-GDP ratio (positively for revenue instruments, negatively for expenditure instruments). As the literature shows, it generally suffices to assume a small and inertial responsiveness of the chosen instrument(s) to 
deviations in the debt ratio (see Bohn 1998). In principle, the government could use all the instruments to stabilize the debt-to-GDP ratio separately or use any mix of the instruments. As we are primarily interested in the "pure" effects of the labor market reforms in the analysis to follow, we assume that the government uses lump-sum taxes as the fiscal instrument to avoid distortions stemming from the fiscal side. ${ }^{7}$ Hence, lump-sum taxes adapt according to the following rule:

$$
\log \left(\frac{T_{t}}{\bar{T}}\right)=\rho_{T} \cdot \log \left(\frac{T_{t-1}}{\bar{T}}\right)+\left(1-\rho_{T}\right) \phi_{T} \cdot \log \left(\frac{b_{t-1}}{\omega^{b} Y_{t-1}^{t o t}} p_{B t-1}^{1-\omega-\psi}\right)+\epsilon_{t}^{T}
$$

where $\epsilon_{t}^{T}$ represents a potential iid shock, $\rho_{T}$ is a smoothing parameter and $\phi_{T}$ the fiscal authority's stance of debt deviations from target. All other fiscal instruments are treated as constants.

\subsection{The foreign country block, international linkages and union-wide monetary policy}

In this section, we will describe some structural relationships corresponding to the foreign country block, point out the international linkages via trade in goods and foreign assets, and describe the union-wide monetary policy rule.

\subsubsection{The foreign country}

We use asterisks to denote decisions made by foreign agents as well as structural parameters in the foreign country. The latter is modelled analogously to the home country. For this reason, here we discuss only some structural relationships, while the full set of equations corresponding to the foreign country is analogous to the home country.

The consumption basket of foreign households is given by:

$$
c_{t}^{i *}=\left(\frac{c_{A t}^{i *}}{\omega-\psi^{*}}\right)^{\omega-\psi^{*}}\left(\frac{c_{B t}^{i *}}{1-\omega+\psi^{*}}\right)^{1-\omega+\psi^{*}}
$$

for $i=o, r$, where $c_{A t}^{i *}$ and $c_{B t}^{i *}$ denote consumption by foreign type- $i$ households of goods produced in country A (home) and B (foreign), respectively, while $\psi^{*}$ captures the degree of home bias in foreign households' preferences. The foreign country's investment basket is analogously defined. Remembering that we assume the law of one price, the corresponding consumer price index in the foreign country (which is

\footnotetext{
7 Were we to use, for example, labor income taxes instead, we would introduce additional effects stemming from the fact that those taxes distort the economy. To avoid this, and to focus only on the pure effect of the labor market reform, we chose lump-sum taxes as the instrument. A decrease (increase) in lump-sum taxes can be interpreted as additional fiscal leeway (shortage) induced by the labor market reform.
} 
used as numeraire by households and firms in that country) is given by:

$$
P_{t}^{*}=P_{A t}^{\omega-\psi^{*}} P_{B t}^{1-\omega+\psi^{*}}=P_{B t}\left(\frac{1}{p_{B t}}\right)^{\omega-\psi^{*}} .
$$

Therefore, the foreign country's consumer price inflation evolves according to:

$$
\pi_{t}^{*} \equiv \frac{P_{t}^{*}}{P_{t-1}^{*}}=\pi_{B t}\left(\frac{p_{B t-1}}{p_{B t}}\right)^{\omega-\psi^{*}},
$$

where $\pi_{B t} \equiv P_{B t} / P_{B t-1}$ is producer price inflation in the foreign country. The PPI itself evolves according to:

$$
\begin{aligned}
P_{B t} & =\left(\int_{0}^{1-\omega} \frac{1}{1-\omega} P_{B t}(j)^{1-\epsilon^{*}} d j\right)^{1 /\left(1-\epsilon^{*}\right)} \\
& =\left[\theta_{P}^{*}\left(P_{B t-1}\right)^{1-\epsilon^{*}}+\left(1-\theta_{P}^{*}\right)\left(\tilde{P}_{B t}\right)^{1-\epsilon^{*}}\right]^{1 /\left(1-\epsilon^{*}\right)},
\end{aligned}
$$

where $\tilde{P}_{B t}$ is the common nominal price chosen by the foreign country's price-setters in period $t$. Also, the nominal interest rate paid/received by the foreign country's nationals on international bonds equals $R_{t}^{e c b} \exp \left(-\psi_{d}\left(d_{t}^{*}-\bar{d}^{*}\right) / Y_{t}^{*}\right)$, where $(-) d_{t}^{*} / Y_{t}^{*}$ is the foreign country's ratio of net foreign debt over output.

\subsubsection{International linkages}

As already mentioned, international linkages between the two countries result from trade in goods and services as well as from trading in international bonds. The home country's net foreign asset position, expressed in terms of PPI, evolves according to:

$$
d_{t}=\frac{R_{t-1}^{e c b} \cdot e^{-\psi_{d}\left(d_{t-1}-\bar{d}\right) / Y_{t-1}}}{\pi_{A t}} \cdot d_{t-1}+\underbrace{\frac{1-\omega}{\omega}\left(C_{A t}^{*}+I_{A t}^{*}\right)-p_{B t}\left(C_{B t}+I_{B t}\right)}_{=\text {Trade balance }},
$$

where $(1-\omega)\left(C_{A t}^{*}+I_{A t}^{*}\right) / \omega$ are real per capita exports and $p_{B t}\left(C_{B t}+I_{B t}\right)$ are real per capita imports. Zero net supply of international bonds implies:

$$
\omega d_{t}+(1-\omega) p_{t}^{B} d_{t}^{*}=0
$$

Finally, terms of trade $p_{B t}=P_{B t} / P_{A t}$ evolve according to:

$$
p_{B t}=\frac{\pi_{B t}}{\pi_{A t}} p_{B t-1}
$$




\subsubsection{Equilibrium in goods markets and GDP}

Market clearing implies that private per capita production in the home and foreign country, $Y_{t}$ and $Y_{t}^{*}$ respectively, is used for private and public consumption as well as private and public investment demand,

$$
\begin{aligned}
& Y_{t}=C_{A t}+I_{A t}+C_{t}^{g}+I_{t}^{g}+\frac{1-\omega}{\omega}\left(C_{A t}^{*}+I_{A t}^{*}\right), \\
& Y_{t}^{*}=C_{B t}^{*}+I_{B t}^{*}+C_{t}^{g *}+I_{t}^{g *}+\frac{\omega}{1-\omega}\left(C_{B t}+I_{B t}\right) .
\end{aligned}
$$

Consistently with national accounting, each country's GDP is the sum of private-sector production and government production of goods and services. The latter is measured at input costs, that is, by the gross government wage bill. Let $Y_{t}^{t o t}$ and $Y_{t}^{t o t}$, ${ }^{\text {to }}$ denote real (PPI-deflated) per capita GDP in the home and foreign country, respectively. We then have:

$$
\begin{aligned}
& Y_{t}^{t o t}=Y_{t}+\left(1+\tau_{t}^{s c}\right) w_{t}^{g} N_{t}^{g} p_{B t}^{1-\omega-\psi} \\
& Y_{t}^{t o t, *}=Y_{t}^{*}+\left(1+\tau_{t}^{s c *}\right) w_{t}^{g *} N_{t}^{g *} p_{B t}^{-\left(\omega-\psi^{*}\right)}
\end{aligned}
$$

where in (42) we have used $P_{t}^{*} / P_{B t}=p_{B t}^{-\left(\omega-\psi^{*}\right)}$.

\subsubsection{Monetary authority}

We assume that the area-wide monetary authority has its nominal interest rate, $R_{t}^{e c b}$, respond to deviations of area-wide CPI inflation from its long-run target, $\bar{\pi}$, and to area-wide GDP growth, according to a simple Taylor rule,

$\frac{R_{t}^{e c b}}{\bar{R}^{e c b}}=\left(\frac{R_{t-1}^{e c b}}{\bar{R}^{e c b}}\right)^{\rho_{R}}\left\{\left[\left(\frac{\pi_{t}}{\bar{\pi}}\right)^{\omega}\left(\frac{\pi_{t}^{*}}{\bar{\pi}^{*}}\right)^{1-\omega}\right]^{\phi_{\pi}}\left[\left(\frac{Y_{t}^{t o t}}{Y_{t-1}^{t o t}}\right)^{\omega}\left(\frac{Y_{t}^{t o t, *}}{Y_{t-1}^{t o t, *}}\right)^{1-\omega}\right]^{\phi_{y}}\right\}^{\left(1-\rho_{R}\right)}$,

where $\rho_{R}$ is a smoothing parameter, $\phi_{\pi}$ and $\phi_{y}$ are the monetary policy's stance on inflation and output growth, respectively. This completes the model description. We now turn to the model calibration.

\subsection{Calibration}

In calibrating our model, we strongly rely on Stähler and Thomas (2012). This means that the model is calibrated to Spain (country $A$ ) and the rest of EMU (country $B$ ) at quarterly frequencies. Spain's country size is set to $\omega=0.10$, which roughly corresponds to Spain's population share in the EMU, while the remaining parameters are calibrated as follows. Some parameters are chosen such that the model's deterministic steady state replicates a number of long-run targets in the data. These long-run targets 
for Spain and for the rest of EMU are displayed in Table 1. The data comes from the European Commission (AMECO and Public Finance Report-2010), Eurostat (NEW CRONOS), Spain's Encuesta de Población Activa (EPA) and the OECD (see http:// www.oecd.org/els/social/workincentives). From this, we set the steady-state shares of different government spending-to-GDP ratios and calculate implicit tax as well as unemployment rates. For the sake of brevity, readers interested in a precise description and derivation are referred to the calibration section in Stähler and Thomas (2012). Steady state values of endogenous variables are indicated by bars.

The rest of the parameters are set according to microeconomic evidence as well as following the literature. A summary of all structural parameters can be found in Table 2. Again, this closely follows Stähler and Thomas (2012) and the reader is referred to there for further details. Unless explicitly stated otherwise, we assume a symmetric calibration between the home and foreign country.

Given the extension of the model, i.e. the inclusion of endogenous job destruction, we have to change calibration partly to still meet the targets we are aiming at. However, this only applies to few parameters that have to be calculated "endogenously" in order to meet the targets. Those parameters set according to microeconomic evidence and literature remain as in Stähler and Thomas (2012). The necessary changes are described in more detail in the following. Regarding the log-normal distribution of idiosyncratic productivity, $\log \left(h_{t}\right) \sim N\left(\mu_{h}, \sigma_{h}\right)$, we follow Costain et al. (2010) and Thomas and Zanetti (2009), who calibrate their models to Spain and the euro area, respectively. This implies that we set $\mu_{h}=\mu_{h}^{*}=0$, implying $E_{t}\left(h_{t}\right)=1$, and $\sigma_{h}=\sigma_{h}^{*}=0.25 .{ }^{8} \mathrm{We}$ stick to the assumption that total steady-state dismissal probability in the private sector is $\bar{s}^{p}=0.06$, while the probability in the public sector is half of that in the private sector, $s^{g}=1 / 2 \cdot \bar{s}^{p}=0.03$. In the present setup with endogenous job destruction, we now have to determine the exogenous dismissal probability in the private sector, too. Given the interpretation that this may refer to the retirement decision, we set $s^{x}=s^{g}=0.03$. With this, we are able to calculate the endogenous private-sector dismissal probability as $\bar{s}^{n}=\left(\bar{s}^{p}-s^{x}\right) /\left(1-s^{x}\right)=F(\overline{\tilde{h}})$, from which we are able to derive the corresponding productivity threshold for firms, i.e. $\overline{\tilde{h}}=F^{-1}(\cdot)$ in the steady state. For the firing costs, we assume that they amount to $30 \%$ of the quarterly average real wage in Spain, i.e. $\kappa^{F}=0.3 \cdot \bar{w}^{p}$, and to $20 \%$ in the rest of EMU, i.e. $\kappa^{F, *}=0.2 \cdot \bar{w}^{p, *}$ (see Thomas and Zanetti 2009, for discussion). As in Stähler and Thomas (2012), the values for private-sector and public-sector matching efficiency $\kappa_{e}^{p}$ and $\kappa_{e}^{g}$ and private-sector vacancy posting costs $\kappa_{v}^{p}$ as well as the corresponding foreign country counterparts, have to be derived "endogenously" to meet the targets. Here, we have to derive unemployment benefits $\kappa^{B}$ from the steady-sate JD equation in order to meet the endogenous dismissal rate, too. All these "endogenously derived" parameter values differ somewhat from those in Stähler and Thomas (2012), but not significantly. Despite the changes, we are still able to analytically solve for the model's deterministic steady state.

\footnotetext{
8 Given the lack of micro evidence on this latter parameter, we additionally conduct robustness analyses by considering four different values of $\sigma_{h}: 0.20,0.30,0.40$ and 0.50 . The results we derive are not changed qualitatively.
} 
Table 1 Targeted values

\begin{tabular}{|c|c|c|}
\hline Target & Symbol & Value \\
\hline \multicolumn{3}{|l|}{ Home country (Spain) } \\
\hline PPI inflation & $\bar{\pi}_{A}$ & 1.0000 \\
\hline Current account & $\bar{d}=-\bar{d}^{*}$ & 0.0000 \\
\hline (Average) Labor income tax rate & $\bar{\tau}^{w}$ & 0.1622 \\
\hline Bond tax rate & $\bar{\tau}^{b}$ & 0.1622 \\
\hline VAT rate & $\bar{\tau}^{c}$ & 0.0762 \\
\hline Social security contribution rate & $\bar{\tau} s c$ & 0.1555 \\
\hline Capital tax rate & $\bar{\tau}^{k}$ & 0.1806 \\
\hline Unemployment rate & $\bar{U}$ & 0.1113 \\
\hline Fraction of publ. employment & fracpub $=\frac{\bar{N}^{g}}{1-\bar{U}}$ & 0.1872 \\
\hline Vacancy filling rate (private) & $\bar{q}^{p}$ & 0.7000 \\
\hline Vacancy filling rate (public) & $\bar{q}^{g}$ & 0.8000 \\
\hline Gov. SS spending & $\omega^{G}=\bar{G} / \bar{Y}^{t o t}$ & 0.2131 \\
\hline Gov. SS purchases & $\omega^{C g}=\bar{C}^{g} / \bar{Y}^{t o t}$ & 0.0756 \\
\hline Gov. SS investment & $\omega^{I g}=\bar{I}^{g} / \bar{Y}^{t o t}$ & 0.0355 \\
\hline SS debt-to-annual-GDP ratio & $\omega^{b}=\bar{p}_{B}^{1-\omega-\psi} \bar{b} /\left(4 \bar{Y}^{t o t}\right)$ & 0.4831 \\
\hline SS subsidy-to-GDP ratio & $\omega^{s}=\bar{p}_{B}^{1-\omega-\psi} \overline{S u}^{-} b / \bar{Y}^{t o t}$ & 0.1543 \\
\hline \multicolumn{3}{|l|}{ Foreign country (rest of EMU) } \\
\hline (Average) Labor income tax rate & $\bar{\tau}^{w *}$ & 0.2225 \\
\hline Bond tax rate & $\bar{\tau}^{b *}$ & 0.1267 \\
\hline VAT rate & $\bar{\tau}^{c *}$ & 0.0995 \\
\hline Social security contribution rate & $\bar{\tau}^{s c *}$ & 0.1706 \\
\hline Capital tax rate & $\bar{\tau}^{k *}$ & 0.0704 \\
\hline Unemployment rate & $\bar{U}^{*}$ & 0.0844 \\
\hline Fraction of publ. employment & fracpub ${ }^{*}=\frac{\bar{N}^{g *}}{1-\bar{U}^{*}}$ & 0.1814 \\
\hline Vacancy filling rate (private) & $\bar{q}^{p *}$ & 0.7000 \\
\hline Vacancy filling rate (public) & $\bar{q}^{g *}$ & 0.8000 \\
\hline Gov. SS spending & $\omega^{G *}=\bar{G}^{*} / \bar{Y}^{t o t *}$ & 0.2256 \\
\hline Gov. SS purchases & $\omega^{C g *}=\bar{C}^{g *} / \bar{Y}^{t o t *}$ & 0.0985 \\
\hline Gov. SS investment & $\omega^{I g *}=\bar{I}^{g *} / \bar{Y}^{t o t *}$ & 0.0238 \\
\hline SS debt-to-GDP ratio (annualized) & $\omega^{b *}=\left(\bar{p}_{B}^{*}\right)^{-\left(\omega-\psi^{*}\right)} \bar{b}^{*} /\left(4 \bar{Y}^{t o t *}\right)$ & 0.6896 \\
\hline SS subsidy-to-GDP ratio & $\omega^{s *}=\left(\bar{p}_{B}^{*}\right)^{-\left(\omega-\psi^{*}\right)} S_{\bar{u}}^{-} b^{*} / \bar{Y}^{t o t *}$ & 0.2126 \\
\hline
\end{tabular}

Sources: Original data from European Commission, Eurostat and OECD, own calculations for the ratios and implicit tax rates; normalization as described in Stähler and Thomas (2012)

\section{Analysis}

In this section, we first describe the simulation design and then discuss the short and long-run results, respectively. Here, it seems worthwhile noting that our calibra- 
Table 2 Baseline parameter calibration

\begin{tabular}{|c|c|c|}
\hline Parameter & Symbol & Value \\
\hline Relative size of home country & $\omega$ & 0.1 \\
\hline \multicolumn{3}{|l|}{ Monetary policy } \\
\hline Interest rate smoothing & $\rho_{R}$ & 0.9 \\
\hline Stance on inflation & $\phi_{\pi}$ & 1.5 \\
\hline Stance on output gap & $\phi_{y}$ & 0.5 \\
\hline \multicolumn{3}{|l|}{ Fiscal policy } \\
\hline Lump-sum tax smoothing & $\rho_{T}=\rho_{T}^{*}$ & 0 \\
\hline Stance on debt (lump-sum tax) & $\phi_{T}=\phi_{T}^{*}$ & 0.9 \\
\hline \multicolumn{3}{|l|}{ Price stickiness } \\
\hline Calvo parameter (prices) & $\theta_{P}$ & 0.75 \\
\hline Market power (markup) & $\epsilon$ & 6 \\
\hline \multicolumn{3}{|l|}{ Trade in international bonds } \\
\hline Risk premium parameter & $\psi_{2}=\psi_{2}^{*}$ & 0.01 \\
\hline \multicolumn{3}{|l|}{ Preferences } \\
\hline Share of RoT consumers & $\mu$ & 0.4 \\
\hline Discount rate & $\beta$ & 0.99 \\
\hline Risk aversion & $\sigma_{c}$ & 2 \\
\hline Habits in consumption & $h$ & 0.85 \\
\hline Home bias & $\psi ; \psi^{*}$ & $0.56 ; 0.03$ \\
\hline \multicolumn{3}{|l|}{ Production } \\
\hline Private-sector capital depreciation & $\delta^{k}$ & 0.025 \\
\hline Public-sector capital depreciation & $\delta^{g}$ & 0.025 \\
\hline Private-sector capital share in prod. & $\alpha$ & 0.4 \\
\hline Public-sector capital influence in prod. & $\eta$ & 0.015 \\
\hline Adjustment cost parameter & $\kappa_{I}$ & 2.48 \\
\hline TFP scaling parameter & $\epsilon^{a} ; \epsilon^{a *}$ & $0.42 ; 0.44$ \\
\hline \multicolumn{3}{|l|}{ Idiosyncratic productivity shock } \\
\hline Mean & $\mu_{h} \Rightarrow E\left\{h_{t}\right\}=1$ & 0 \\
\hline Standard deviation & $\sigma_{h}$ & 0.25 \\
\hline \multicolumn{3}{|l|}{ Labor market } \\
\hline Matching elasticity (private sector) & $\varphi^{p}$ & 0.5 \\
\hline Matching elasticity (public sector) & $\varphi^{g}$ & 0.3 \\
\hline Separation rate (public sector) & $s^{g}$ & 0.03 \\
\hline Ex separation rate (private sector) & $s^{x}$ & 0.03 \\
\hline Bargaining power & $\xi$ & 0.5 \\
\hline Private-sector matching efficiency & $\kappa_{e}^{p} ; \kappa_{e}^{p *}$ & $0.44 ; 0.48$ \\
\hline Public-sector sector matching efficiency & $\kappa_{e}^{g} ; \kappa_{e}^{g *}$ & $0.30 ; 0.32$ \\
\hline Vacancy posting costs & $\kappa_{v}^{p}=\kappa_{v}^{g} ; \kappa_{v}^{p, *}=\kappa_{v}^{g, *}$ & $0.15 ; 0.12$ \\
\hline Unemployment benefits & $\kappa_{B} ; \kappa_{B}^{*}$ & $0.45 ; 0.28$ \\
\hline Dismissal costs & $\kappa^{F} ; \kappa^{F, *}$ & $0.21 ; 0.10$ \\
\hline
\end{tabular}


tion reproduces a downward-sloping Beveridge curve and also a negative correlation between job creation and job destruction to standard shocks. ${ }^{9}$ Hence, the results we discuss below do not result from the fact that, sometimes, DSGE models with frictional labor markets and endogenous job destruction fail to reproduce these features (see, for example, Fujita and Ramey 2005, for a more detailed discussion of this issue).

\subsection{Simulation design}

As discussed in the introduction, the Spanish government announced or implemented measures to reform the labor market in order, first, to foster wage moderation and, second, to make the labor market more flexible. All the measures are supposed to help regain international competitiveness. More precisely, the Spanish government already decreased public wages and employment, which yields a reduction in the workers' outside option in private wage negotiations. Another-from our model perspective somewhat analogous - measure to achieve this is a cut in unemployment benefits. The government announced it will reform the bargaining system and cut dismissal costs in its recent Stability Programme 2011 as well as the National Reform Programme 2011.

In our model, we implement these measures as follows. In line with Zanetti (2011), we assume a permanent ex-ante $5 \%$ points decrease in firing costs (from $30 \%$ of average real wages to $25 \%$ ) and in the replacement ratio (i.e. unemployment benefits form about $67.9-62.9 \%$ of average real wages). We also simulate a permanent ex-ante $5 \%$ point reduction in the union's bargaining power (from 50 to $45 \%$ ). It is important to note that these changes imply changes in many economic variables such that, from the ex-post perspective (i.e. in the new steady state), firing costs, for example, may be higher or lower than $25 \%$ of average real wages because the latter may have changed. Regarding the cut in public-sector wages, we refer the reader to Stähler and Thomas (2012) for a more detailed discussion of the effects at work to save space and because the effects are perfectly analogous to a model without exogenous job destruction. ${ }^{10}$ We also discuss a $5 \%$ decrease in public employment in the present paper.

As structural changes in labor market parameters imply changes in many other economic variables on the transition to the new steady state, and in the new steady state itself, public balances also change. For example, if labor market reforms yield an increase of domestic consumption, consumption tax revenues increase, implying that debt can be decreased. A lower level of debt means lower interest payments on outstanding debt, so the government may have additional leeway to further cut taxes or increase expenditures. Should the labor market reform deteriorate public finances, the opposite is true, of course. In order to guarantee stability of the system without

\footnotetext{
9 Including shock processes broadly in line with those estimated by Andrés et al. (2010), we find the correlation between vacancies and unemployment to be $\rho\left(v_{t}^{p}, U_{t}\right)=-0.48$ on the aggregate level. For the dismissal threshold and vacancy posting, the correlation is $\rho\left(p_{t}^{p}, \tilde{h}_{t}\right)=-0.99$. These values are also similar to those reported in Thomas and Zanetti (2009).

10 Except some slight variations in the GDP movements resulting from the definition of GDP, which includes the public sector wage bill in our model, the effects are also analogous to a cut in unemployment benefits. We show the latter simulation in this paper. To prove our claim, we provide the corresponding graphs of the wage simulation in the Appendix of the working paper version of this paper (Schwarzmüller and Stähler 2011).
} 
introducing additional distortions, we assume that the government uses lump-sum taxes to take care of these effects. We already discussed the issue in Sect. 2.4. In the next subsection, we analyze the effects of the above mentioned labor market reforms in more detail.

\subsection{Simulation results}

We start off by analyzing the short-run effects of the measures discussed above. Here, we plot the dynamic responses for the first 20 quarters after the measure has been conducted. At the end of this subsection, we discuss the long-run implications of the labor market reforms and have a look at the spillovers to the rest of EMU.

\subsubsection{Dynamic effects}

To get started, it seems appropriate to first have a look at the most intuitive reform, the cut in unemployment benefits. Figure 1 plots the dynamic responses for selected variables. A cut in unemployment benefits deteriorates the workers' outside option such that wages fall, which implies that job destruction-shown as the endogenous dismissal rate in the lowest-left panel of Fig. 1-also falls because maintaining a worker becomes more attractive due to lower labor costs. This, in turn, means that the expected value of a newly created job increases because the expected job duration rises. Hence, the job finding probability for workers increases. Less job destruction and higher job creation generate more employment and unemployment falls. Lower labor costs also allow firms to reduce prices, which improves the terms of trade, fosters demand for Spanish goods in the rest of EMU and, thus, increases exports. Internal demand also increases because of improvements in fiscal balances and the resulting positive wealth effect. RoT-consumers, however, consume less. This is because the drop in wages cannot be compensated for by the increase in the employment level. Nevertheless, optimizers, for whom the wealth effect is relevant, eventually dominate the private consumption pattern. ${ }^{11}$ Imports initially fall because Spanish goods become relatively cheaper, but the higher internal demand eventually pushes real imports up. Because Spain is relatively small, the price changes in Spain lead to only modest reactions of the ECB rate as well as the interest rate on domestic bonds. The higher product demand is satisfied by higher output and GDP.

A cut in public wages yields similar effects, both qualitatively and quantitatively. The only difference is that, now, the workers' outside option is diminished by the fact that, when finding a public-sector job, its remuneration is lower (see Stähler and Thomas 2012). As Fig. 2 reveals, cutting the union's bargaining power implies analogous qualitative effects because of the wage decrease resulting from less bargaining power; however, at a quantitatively lower level. In this regard, it is interesting to note that, when assuming a two-tier wage contract-i.e. different wages for continuing

\footnotetext{
11 We use the word "dominate" as a short-cut. To be more precise, optimizers "foresee" a future income increase. When the increase is realized, RoTs will respond, too (more precisely, this reasoning is correct when optimizers are responding to wealth effects, but not when they are responding to intertemporal substitution effects).
} 


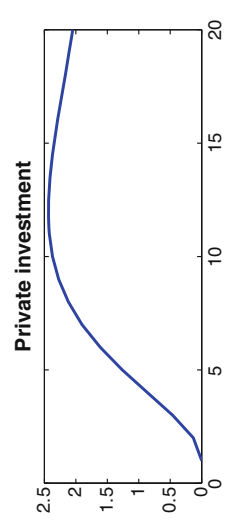

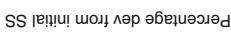

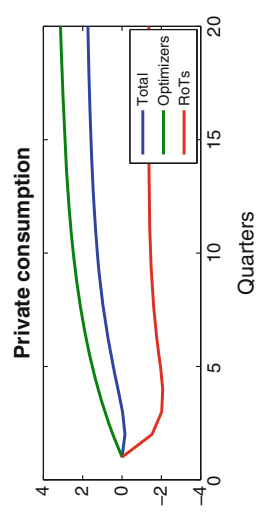

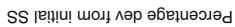

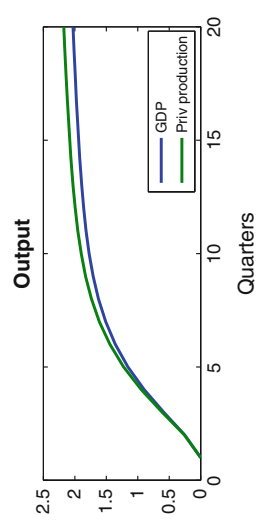

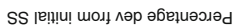

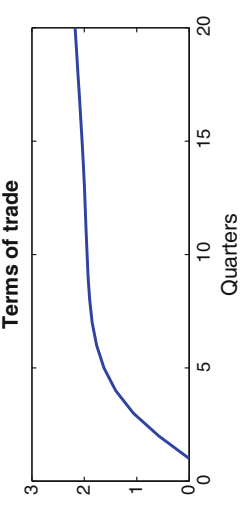

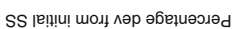

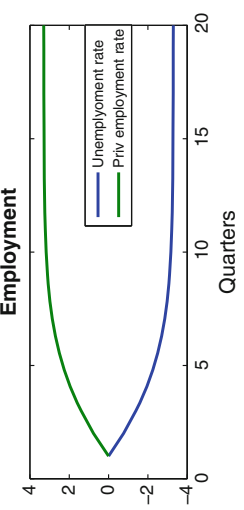

SS |е!!!u! moג ^әр ұu!̣d-d

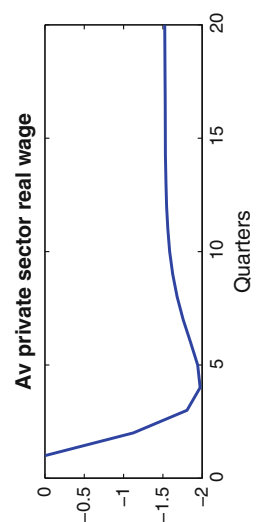

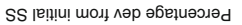

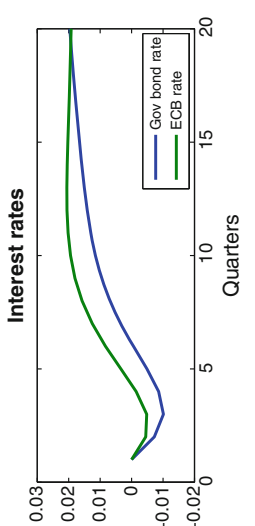

SS |е!!!u! moxt ләр ұu!od-d

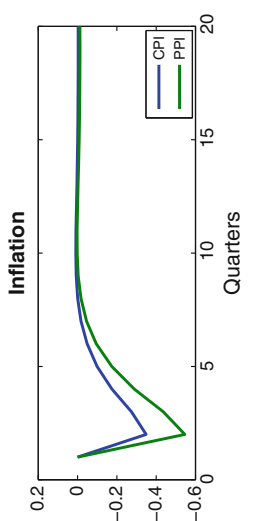

SS ןe!!!u! moג ^әр ұu!od-d

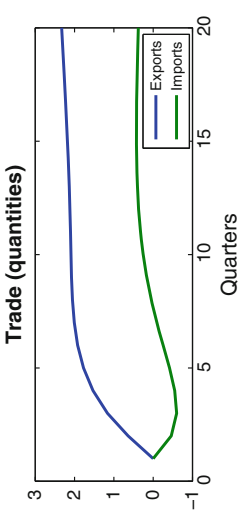

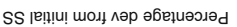

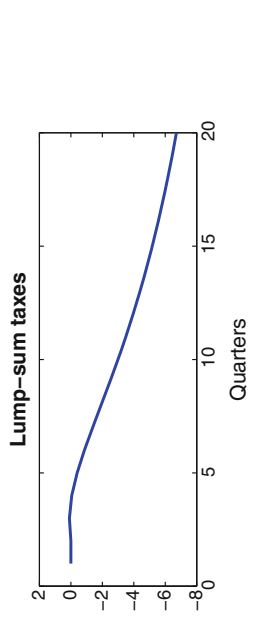

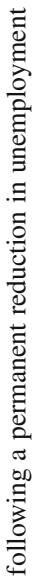

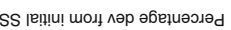

焉.

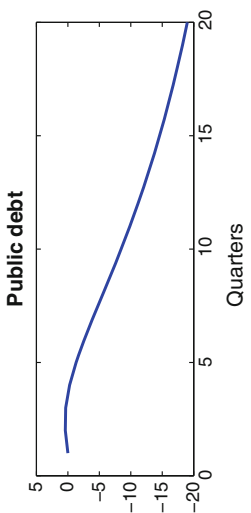

苞

¿

घี

․․․

离

这

पे

乌ิ

灵

芯芯

:

䆑主

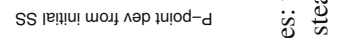

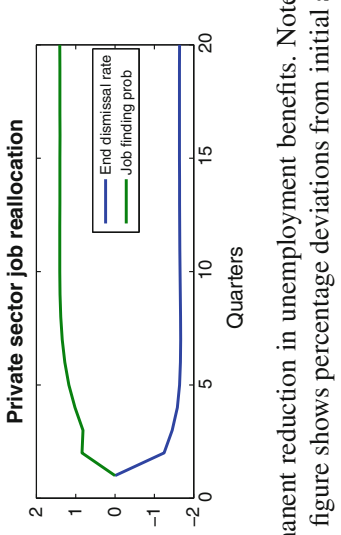

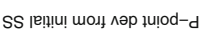

है Е

- 

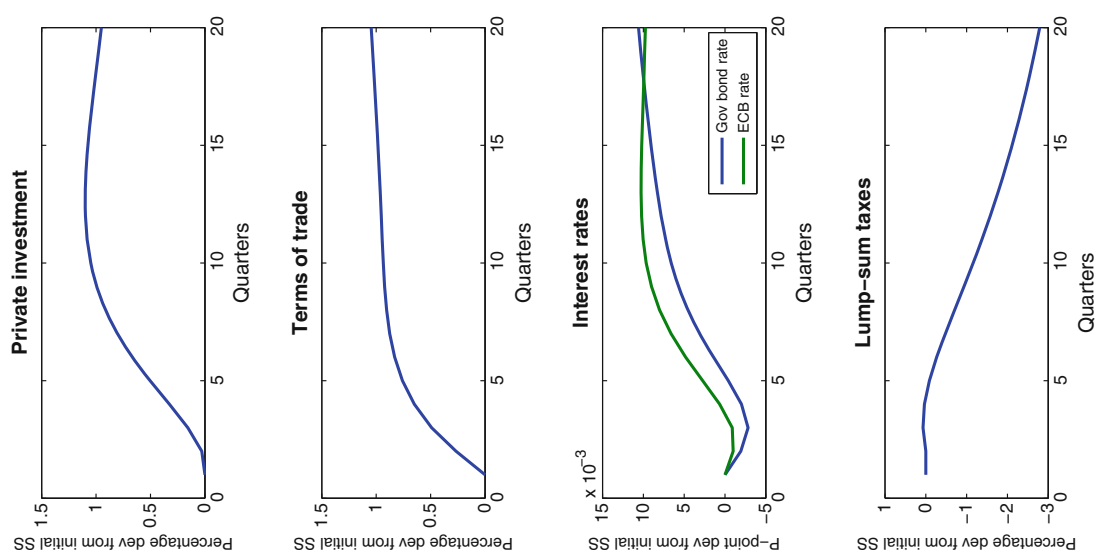

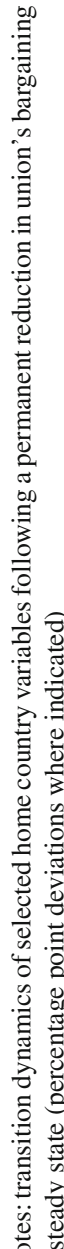
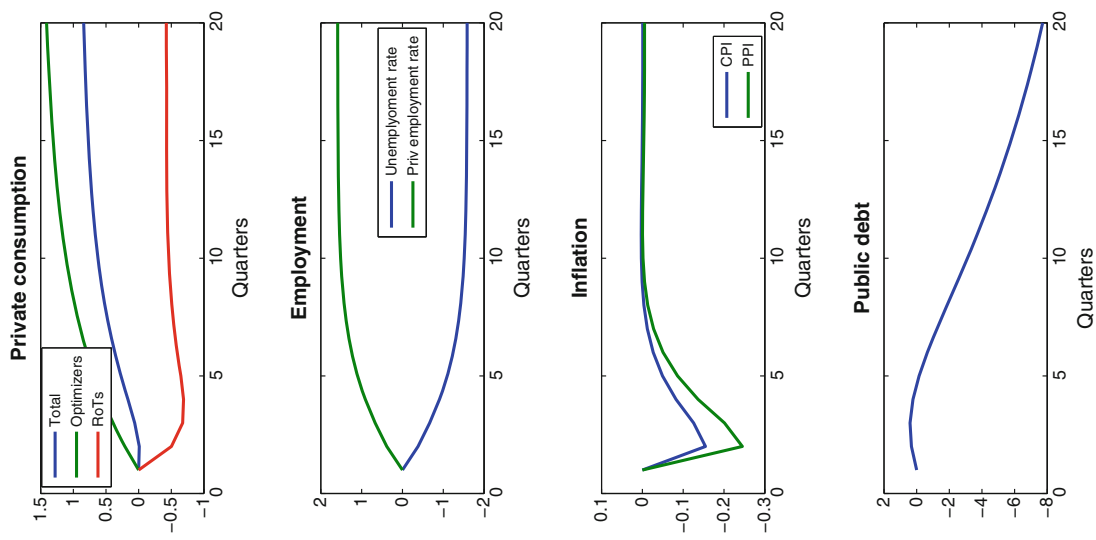

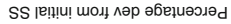

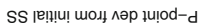

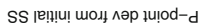
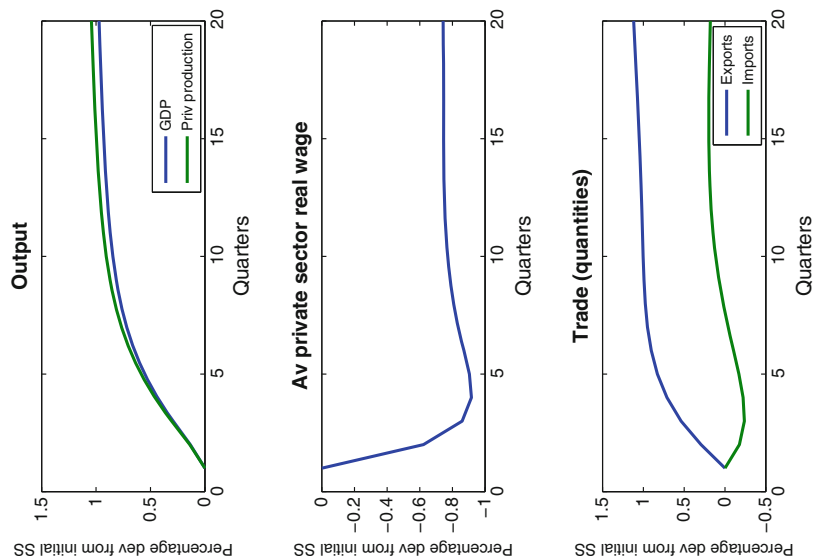

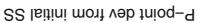

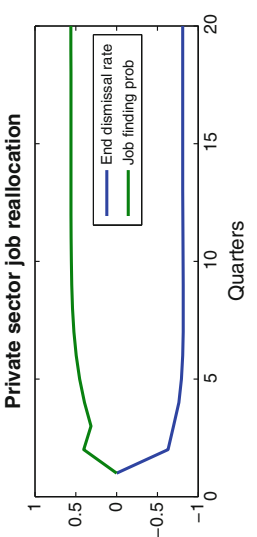

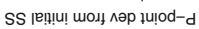

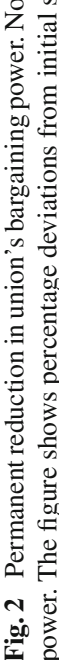


and newly hired workers as in Mortensen and Pissarides (1994) or Zanetti (2011)—, we can observed higher job creation and destruction following a cut in the workers' bargaining power. This is because the two-tier wage structure increases the incentive for firms to lay off relatively unproductive workers in continuing job to hire new, more productive ones. Readers interested in more details on this effect are referred to the working paper version of this paper (Schwarzmüller and Stähler 2011). ${ }^{12}$

The effects of a decrease in firing costs-another more or less standard issue in labor market analyses (see, for example, Mortensen and Pissarides 1999, 2003; or Stähler 2007, Chap. 3, for an overview of the literature) -are summarized in Fig. 3. Because dismissals become cheaper, firms are more inclined to lay off a worker and, thus, the reservation threshold $\tilde{h}_{t}$ increases. Nevertheless, the expected costs of getting rid of a worker once hired also decrease, inducing firms to create more vacancies. Because the latter effect always dominates, job creation rises. Formally, this can be seen in the JC, Eq. (32). Those are standard effects in the literature, leaving the effects on unemployment ambiguous from a purely theoretical perspective. Our simulation suggests that unemployment increases, which is quite robust to alternative parameterizations of the model.

When firing costs are decreased, the union demands lower wages because they take into account that, were they to demand higher wages, firms would dismiss them even earlier given the already increase dismissal probability due to lower dismissal costs. Higher unemployment deteriorates fiscal balances generating a negative wealth effect for optimizers inducing them to decrease consumption. Lower wages make RoTs do the same. This implies that demand and output decrease. Initially, the wage decrease allows firms to reduce prices, which, on impact, somewhat improves the terms of trade. Imports fall while exports are virtually unaffected. After the first firing round resulting from lower dismissal costs, both job creation and destruction stabilize at higher levels implying higher job turnover at a lower employment level. Even though average productivity per employed worker increases due to the higher dismissal threshold, labor input for intermediate goods producing firms falls, increasing the marginal product of labor, $x_{t}$. This eventually holds for the capital interest rate, $r_{t}^{k}$, too, which then increases marginal costs and induces firms to increase prices, setting in train the eventual deterioration of the terms of trade and the decrease in exports. Still, interest rates barely move due to Spain's small size within EMU.

Summing up, we learn from our analysis that decreasing employment protection to foster international competitiveness may not work-at least not as easily as is often claimed in policy reports which frequently state this to be an option without further detailing the issue. At first glance, this may seem surprising, as a more flexible labor market is generally assumed to go hand-in-hand with higher production and international competitiveness. Note, however, that this result does fit into the literature as "on the whole, there is no strong evidence suggesting that reducing EPL (employment protection legislation) would lessen or prevent excessive imbalances in the EU" (see

\footnotetext{
12 This effect does not hinge on the assumption that newly hired workers have maximum productivity. Their productivity must just be somewhat higher than dismissal productivity, which seems a reasonable assumption given that, otherwise, no job creation will take place at all. In the working paper version, Schwarzmüller and Stähler (2011), we also provide the graphs for a reduction in public-sector wages.
} 


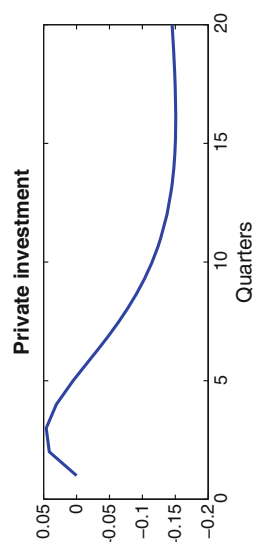

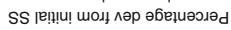

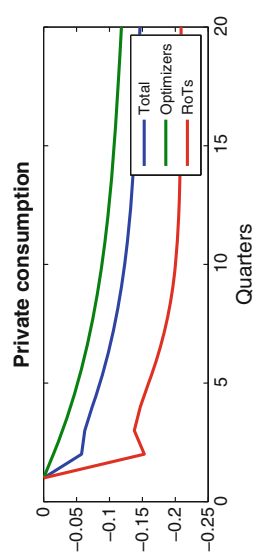

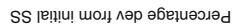

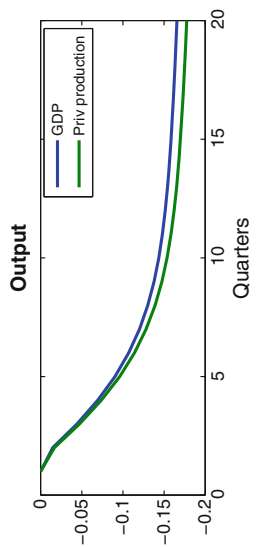

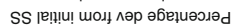

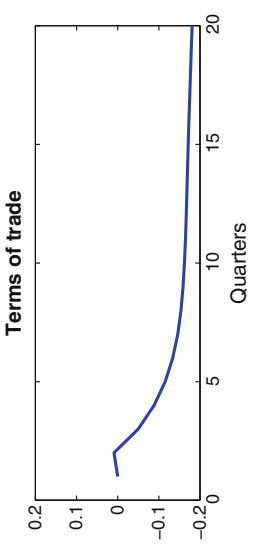

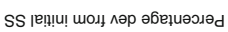

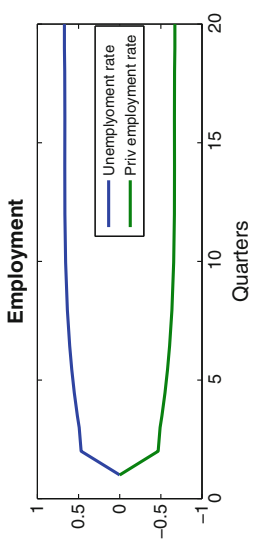

SS |!!u! moגł ^әр ұu!od-d

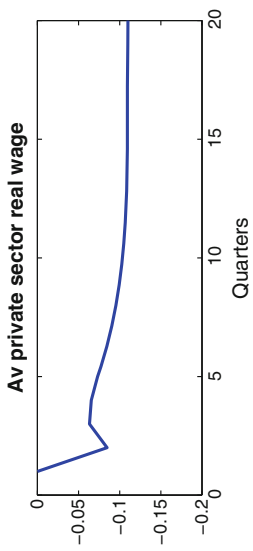

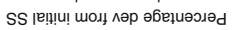

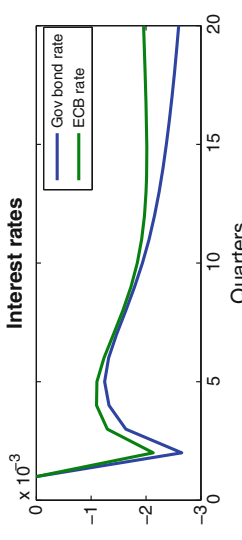

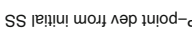

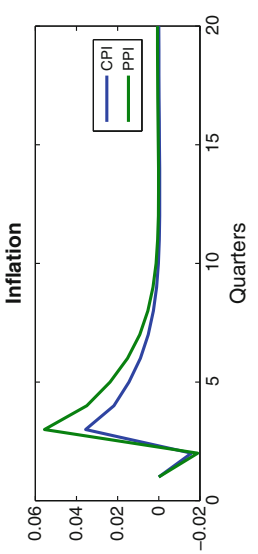

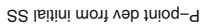

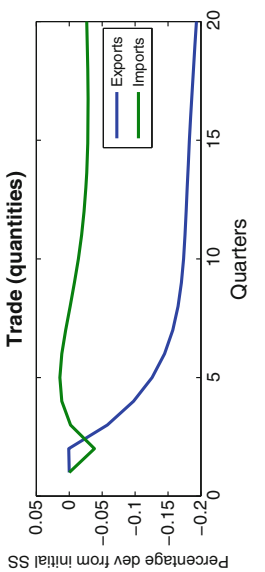

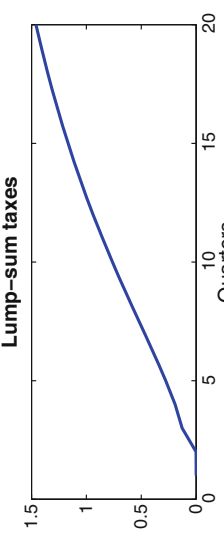

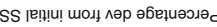

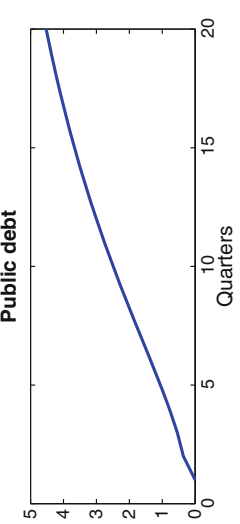

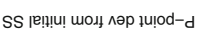

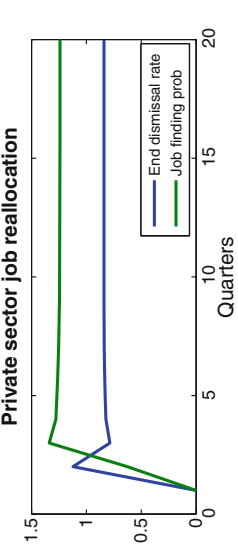

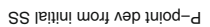

$\frac{n}{5}$

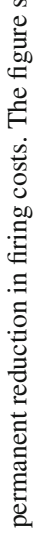

of

흥

๘

$\frac{0}{7}$

ह

จ요

ㄹ.

뉸

皮

is

.

है.

ธำ

:

펑

过

乙

के के

엉 궁

क

袢 严

.

.을

氖

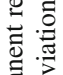

䒕

2.

$m$ 过

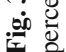


IMF 2011, p. 87 and the literature discussed therein). Furthermore, two more theoretical remarks also seem in order. First, as has been shown in Stähler (2008), when talking about the effects of employment protection on unemployment in matching labor market frameworks, the bargaining structure itself matters. In the model at hand, we more or less follow the conventional approach. It is not unlikely, however, that altering the bargaining game between unions and firms would alter our findings. For example, in the model by Stähler (2008), employment protection is indeed responsible for higher wage claims and higher unemployment rates. Second, Spain is characterized by a highly dual labor market consisting of (potentially less productive) insiders who enjoy a high degree of employment protection, and outsiders who have barely none. Breaking this dual labor market structure and decreasing the average level of employment protection-but augmenting it for some-may be a way to go. For an analysis in this direction, see Costain et al. (2010). Overall, further research on this topic in general equilibrium models is certainly in order.

Figure 4 summarizes the dynamic effects of a cut in public employment. Note that the cut is, in contrast to the other reforms, gradual. ${ }^{13}$ However, this does not affect the long-run results at all, and the short-run effects do not change qualitatively (see Stähler and Thomas 2012, too). We see that, while the effects on private production, private consumption, wages, prices, the terms of trade and fiscal balances are-except in size - analogous to those of a reduction in unemployment benefits or public wages, there are notable differences in the dynamics of GDP, employment and the firms' hiring and firing decisions. This is the case mainly for two reasons. First, the effect on GDP is due to the definition of real GDP itself, namely the sum of private production and government production (measured as the public sector wage bill). The latter falls when dismissing public-sector workers. Second, and probably more interesting, are the dynamics of the labor market and the resulting multiplier-diminishing effects. When cutting public-sector employment, the probability of finding a public-sector job decreases, which yields a drop in the workers' average wage claims. On impact, this increases the probability of unemployed workers finding a job in the private sector because lower wages foster the incentive for private job creation. Nevertheless, higher private job creation does not compensate for the lower public-sector labor demand and, thus, the private-sector job finding probability eventually falls. To some extent, the decrease in public-sector employment can be interpreted as an "unemployment shock" increasing the number of unemployed workers in the economy. We see this by the simultaneous increase of the unemployment rate and the private-sector employment rate in Fig. 4. Furthermore-and in addition to a model with only exogenous (private) job destruction as in Stähler and Thomas (2012) — we see that private-sector job destruction increases (after a short drop on impact). Because of the "unemployment shock", it now pays for firms to dismiss a relatively unproductive worker, pay

\footnotetext{
13 Given our assumption of exogenous separations in the public sector, which is arguably the most realistic one in the case of the government sector, it is physically impossible to implement such a reduction immediately. To see this, consider the law of motion of government employment, $N_{t}^{g}=\left(1-s^{g}\right) N_{t-1}^{g}+p_{t}^{g} \tilde{U}_{t}$. The largest possible percentage reduction in employment, which happens when gross hirings $p_{t}^{g} \tilde{U}_{t}$ drop to zero, is given by $s^{g}$, which equals $3 \%$ under our calibration. Therefore, even under an extreme policy of complete hiring freeze, the required employment reduction would still have to be implemented gradually.
} 


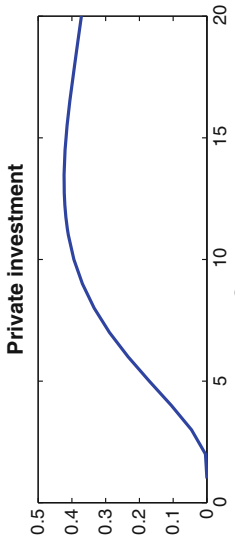

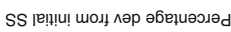

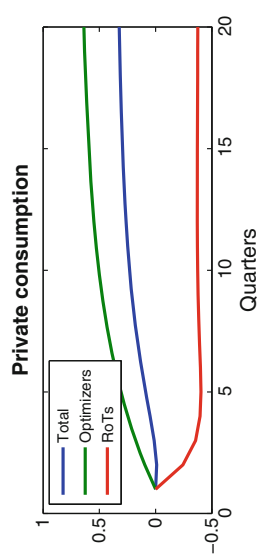

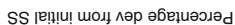

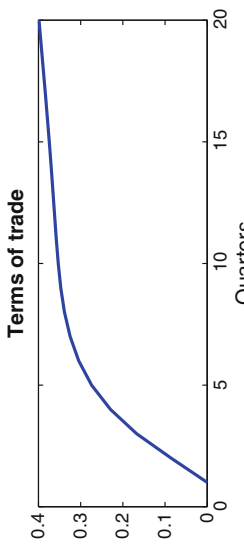

SS ןе!!!u! سод ^әр әбеұиәэәд

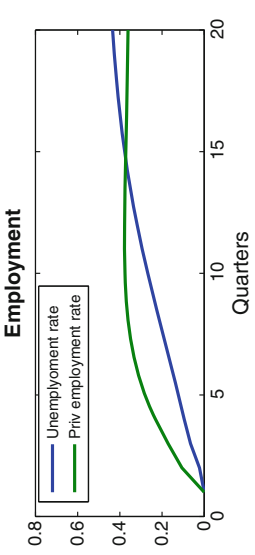

SS ןе!!!u! سодł ^әр ұu!od-d

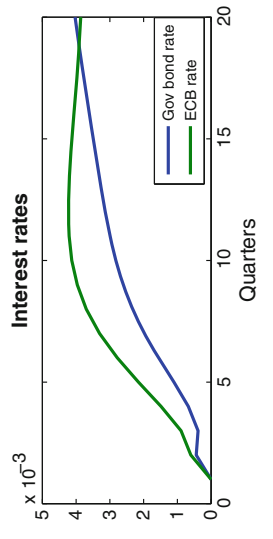

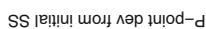

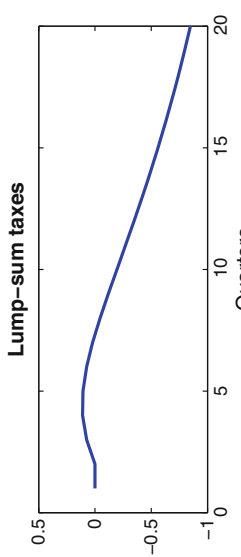

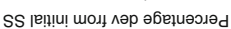
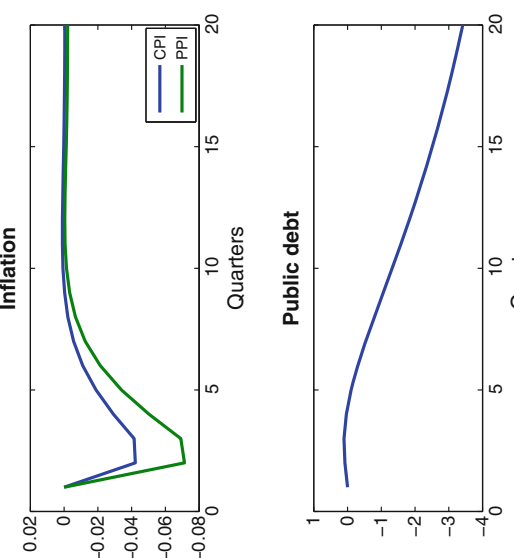

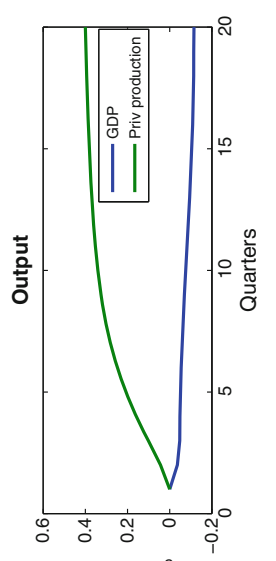

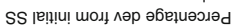

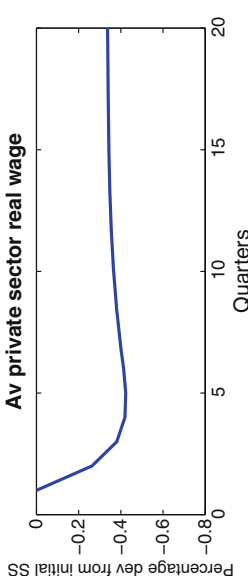

SS |еп!!u! mоды ^әр ұu!̣d-d

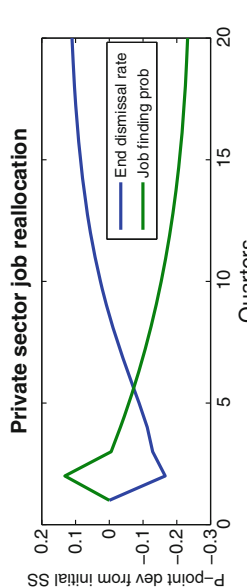
을

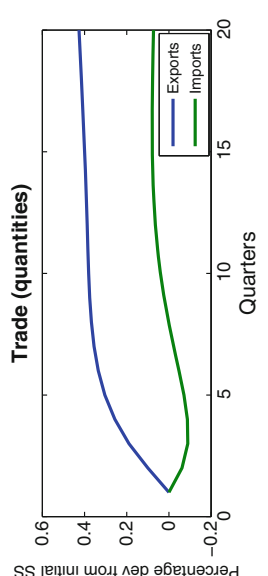

旁胥

를

를

을 증 
the search costs and hire a new, more productive, one as average search duration (from the firms' perspective) has fallen to a sufficient extent for such a behavior to pay off. Given the differences in the effects on the labor market-especially, the "unemployment shock"-, it is no longer surprising that the effects on the other variables (such as private production, prices, consumptions, and the terms of trade) turn out to be much smaller than when cutting unemployment benefits or public-sector wages.

\subsubsection{Long-run effects}

In Table 3, we present the steady-sate effects of the labor market reforms discussed in the previous subsection on selected home-country variables, while Table 4 shows the long-run spillovers of these reforms to the rest of EMU. The tables present percentage deviations from the initial steady state (percentage point deviations as indicated). The long-run effects are the result of both the permanent labor market reform and the long-run impact on lump-sum taxes. As lump-sum taxes introduce no further distortions in the system, they can be interpreted as the fiscal leeway (if negative) or the fiscal shortage (if positive) resulting from the reform. We discussed this issue above.

Comparing the long-run results in Table 3, we find that measures aiming at reducing the workers' (policy-induced) outside option such as the decrease in unemployment benefits $\kappa^{B}$ and public wages $\bar{w}^{g}$, followed by a decrease in the union's bargaining power $\zeta$, is most beneficial for improving output, employment and the terms of trade. Aggregate internal and external demand rises. It also generates, by far, the largest leeway for fiscal balances. The reason is that, by reducing the workers' (policy-induced)

Table 3 Long-run results of different labor market reforms on Spanish economy

\begin{tabular}{|c|c|c|c|c|c|}
\hline $\begin{array}{l}\text { Reduction in } \\
\text { Effect on }\end{array}$ & $\kappa^{B}$ & $\kappa^{F}$ & $\xi$ & $\bar{w}^{g}$ & $\bar{N}^{g}$ \\
\hline Real GDP & 2.59 & -0.24 & 1.29 & 1.87 & -0.01 \\
\hline Real private-sector output & 2.78 & -0.26 & 1.40 & 2.56 & 0.54 \\
\hline Real priv cons (total) & 2.39 & -0.23 & 1.20 & 2.20 & 0.47 \\
\hline Real priv cons (optimizers) & 3.97 & -0.22 & 1.89 & 3.47 & 0.83 \\
\hline Real priv cons (RoTs) & -1.11 & -0.23 & -0.31 & -0.60 & -0.34 \\
\hline Real private investment & 1.88 & -0.18 & 0.94 & 1.73 & 0.37 \\
\hline Unemployment & -3.52 & 0.71 & -1.75 & -3.23 & 0.41 \\
\hline End dismissal rate & -1.72 & 0.86 & -0.88 & -1.60 & 0.10 \\
\hline Job finding prob & 1.64 & 1.22 & 0.67 & 1.45 & -0.21 \\
\hline Av private real wage & -1.30 & -0.13 & -0.65 & -1.20 & -0.30 \\
\hline Terms of trade & 2.64 & -0.24 & 1.32 & 2.43 & 0.52 \\
\hline Lump-sum taxes & -11.75 & 2.40 & -5.26 & -12.04 & -1.96 \\
\hline
\end{tabular}

Notes: the table shows percentage deviations from initial steady state (percentage point deviations for unemployment rates as well as dismissal and job finding probabilities) 
Table 4 Long-run spillovers of different labor market reforms on rest of EMU

\begin{tabular}{|c|c|c|c|c|c|}
\hline $\begin{array}{l}\text { Reduction in } \\
\text { Effect on }\end{array}$ & $\kappa^{B}$ & $\kappa^{F}$ & $\xi$ & $\bar{w}^{g}$ & $\bar{N}^{g}$ \\
\hline Real GDP & 0.38 & -0.04 & 0.19 & 0.35 & 0.08 \\
\hline Real private-sector output & 0.45 & -0.04 & 0.23 & 0.41 & 0.09 \\
\hline Real priv cons (total) & 0.72 & -0.07 & 0.37 & 0.67 & 0.14 \\
\hline Real priv cons (optimizers) & 0.82 & -0.08 & 0.42 & 0.76 & 0.16 \\
\hline Real priv cons (RoTs) & 0.39 & -0.04 & 0.20 & 0.37 & 0.08 \\
\hline Real private investment & 0.63 & -0.06 & 0.32 & 0.58 & 0.12 \\
\hline Unemployment & -0.35 & 0.04 & -0.18 & -0.33 & -0.07 \\
\hline End dismissal rate & -0.19 & 0.02 & -0.10 & -0.18 & -0.04 \\
\hline Job finding prob & 0.31 & -0.03 & 0.15 & 0.28 & 0.06 \\
\hline Av private real wage & 0.32 & -0.03 & 0.17 & 0.30 & 0.07 \\
\hline Lump-sum taxes & -0.96 & 0.09 & -0.49 & -0.88 & -0.19 \\
\hline
\end{tabular}

Notes: the table shows percentage deviations from initial steady state (percentage point deviations for unemployment rates as well as dismissal and job finding probabilities)

outside option, wage claims fall and Spanish goods become relatively cheaper. At the same time, fiscal balances benefit from reducing expenditures, which gives room to additionally reduce taxation because of lower steady-state debt levels further boosting demand. However, it is also evident that RoT-households do not benefit from these measures because the wage drop dominates the rise in employment such that their steady-state consumption possibilities deteriorate while optimizers benefit from the positive wealth effect. The argument also holds for a decrease in public employment, however, to a lesser extent and not for unemployment. This is due, first, to the definition of GDP and, second, to the "unemployment shock"; both are described in the previous section.

Decreasing dismissal costs $\kappa^{F}$ does not improve the labor market situation, as the increase in the dismissal probability dominates the rise in job creation. Neither does it increase output nor the terms of trade. The reason is, as we have already described in the previous section, that higher marginal costs make firms raise prices. Therefore, terms of trade deteriorate. Reforming the employment protection legislation may not be the most suitable measure when planning to improve international competitiveness. However, to draw some important policy conclusions, discussing employment protection legislation reforms most likely deserves a more sophisticated labor market modelling than the one we have offered in the model at hand (see, for example, Stähler 2007, for an overview of the literature on employment protection and some applications of the matching model).

In Table 4, we report the effects the measures conducted in Spain have on the rest of EMU. There are at least three findings worth pointing out. First, whenever the measure raises private-sector output in Spain, it does so for the rest of EMU, too. At first sight, this may be surprising because one might guess that an increase in Spain's international competitiveness resulting from these labor market reforms may harm other member countries. However, the resulting additional demand for foreign 
goods in Spain overcompensates for the loss in competitiveness faced by the rest of EMU countries vis-á-vis Spain, at least on an aggregate level. ${ }^{14}$ Second, all measures beneficial for Spain improve the labor market situation in the rest of EMU. The reason is that the additional demand for foreign goods in Spain is produced by more labor input there, too. Given the improvement in the labor market, yielding (slightly) higher wages, too, we note that, third, liquidity-constrained RoT-consumers do not lose from the reforms in Spain-in contrast to the situation in the reforming country itself.

\section{Conclusions}

In this paper, we have used an extended version of "FiMod-A DSGE Model for Fiscal Policy Simulations" (Stähler and Thomas 2012) with endogenous job destruction decisions by private firms to analyze the effects of permanent cuts in unemployment benefits, public-sector employment and wages, employment protection and the unions' bargaining power on output, employment, international competitiveness and fiscal balances inspired by the current discussion on labor market reforms in Spain. FiMod is a medium-scale two-country monetary union DSGE model with quite a comprehensive fiscal block. Furthermore, it includes the modern theory of unemployment by assuming a frictional labor market.

We find that measures decreasing the policy-induced outside option of workers, such as a cut in unemployment benefits or public wages, seems to be the most effective way to increase output, employment and international competitiveness while, at the same time, improving fiscal balances. The reason is that the effect on the reservation wage feeds through to private-sector wage bargaining almost immediately, while, at the same time, fiscal balances are also directly affected. The same argument holds for cuts in public-sector employment, albeit at a lower level, because the increase in private labor demand cannot compensate for the loss in public-sector employment. Cuts in the unions' bargaining power also achieve the goal of improving competitiveness, output and employment, however, at a lower level. A cut in employment protection does not seem to be an adequate measure to regain international competitiveness. Lower employment protection yields less job security, which may induce workers to demand even higher wages, thereby deteriorating international competitiveness rather than improving it.

Acknowledgments The opinions expressed in this paper do not necessarily reflect the views of the Banco de España, the Deutsche Bundesbank, the Eurosystem, the Kiel Institute for the World Economy or its staff. Any errors are the authors' alone. We would like to thank Niklas Gadatsch, Heinz Herrmann, Johannes Hoffmann, Martin Kliem, Malte Knüppel, Michael Krause, Christian Merkl, Thomas McClymont, Carlos Thomas, Ulf von Kalckreuth and an anonymous referee for helpful comments.

Open Access This article is distributed under the terms of the Creative Commons Attribution License which permits any use, distribution, and reproduction in any medium, provided the original author(s) and the source are credited.

\footnotetext{
${ }^{14}$ Note that, as we model the rest of EMU as one block in the model at hand, it may still be possible that some individual countries lose from the reforms conducted in Spain in practice. Nevertheless, our simulation suggests that, overall, the rest of EMU will benefit.
} 


\section{References}

Almeida V, Castro G, Félix RM, Maria JF (2010) Improving competition in the non-tradable goods and labour markets: the Portuguese case. Portuguese Econ J 9:163-193

Andolfatto D (1996) Business cycles and labor-market search. Am Econ Rev 86:112-132

Andrés J, Hurtado S, Ortega E, Thomas C (2010) Spain in the Euro: a general equilibrium analysis. SERIEs J Span Econ Assoc 1:67-95

Blanchard O, Galí J (2010) Labor markets and monetary policy: a new-Keynesian model with unemployment. Am Econ J Macroecon 2:1-30

Bohn H (1998) The behavior Of U.S. public debt and deficits. Quart J Econ 113:949-963

Boscá JE, Díaz A, Doménech R, Pérez E, Ferri J, Puch L (2010) A rational expectations model for simulation and policy evaluation of the Spanish economy. SERIEs J Span Econ Assoc 1:135-169

Boscá JE, Doménech R, Ferri J (2009) Tax reforms and labour-market performance: an evaluation for Spain using REMS. Moneda y Credito 228:145-188

Boscá JE, Doménech R, Ferri J (2011) Search, Nash bargaining and rule of thumb consumers. Eur Econ Rev 55:927-942

Calvo G (1983) Staggered prices in a utility-maximizing framework. J Monet Econ 12:383-398

Campolmi A, Faia E (2011) Labor market institutions and inflation volatility in the Euro area. J Econ Dyn Control 35:793-812

Christiano L, Eichenbaum M, Evans C (2005) Nominal rigidities and the dynamic effects of a shock to monetary policy. J Political Econ 113:1-45

Christoffel K, Kuester K, Linzert T (2009) The role of labor markets for Euro area monetary policy. Eur Econ Rev 53:908-936

Costain J, Jimeno JF, Thomas C (2010) Employment fluctuations in a dual labor market, Banco de España ( working paper no. 1013)

Deák S, Fontagné L, Maffezzoli M, Marcellino M (2011) LSM: a DSGE model for Luxembourg. Econ Model 28:2862-2872

DeWalque G, Pierrard O, Snessens HS, Wouters R (2009) Sequential bargaining in a new-Keynesian model with frictional unemployment and wage negotiation. Annales d'Economie et de Statistique 95-96:223250

Fujita S, Ramey G (2005) The dynamic beveridge curve, working paper 05-22. Federal Reserve Bank of Philadelphia, Philadelphia

Galí J, Lopez-Salido JD, Vallés J (2007) Understanding the effects of government spending on consumption. J Eur Econ Assoc 5:227-270

IMF (2011) Regional economic outlook, Europe: strengthening the recovery. World Economic and Financial Surveys, May 2011. International Monetary Fund (IMF), Washington

Kilponen J, Ripatti A (2006) Labour and product market competition in a small open economy-simulation results using a DGE model of the Finnish economy. Bank of Finland, Helsinki (research discussion papers, no. 5/2006)

Krause MU, Uhlig H (2012) Transitions in the German labor market: structure and crisis. J Monet Econ 59:64-79

Leeper EM, Walker TB, Yang SCS (2010) Government investment and fiscal stimulus. J Monet Econ 57:1000-1012

Merkl C, Schmitz T (2011) Macroeconomic volatilities and the labor market: first results from the Euro experiment. Eur J Political Econ 27:44-60

Merz M (1995) Search in the labor market and the real business cycle. J Monet Econ 36:269-300

Mortensen DT, Pissarides C (1994) Job creation and job destruction in the theory of unemployment. Rev Econ Stud 61:397-415

Mortensen DT, Pissarides C (1999) New developments in models of search in the labor market. In: Ashenfelter O, Card D (eds) Handbook of Labor Economics, vol 3B. Elsevier, Amsterdam, pp 2567-2627

Mortensen DT, Pissarides C (2003) Taxes, subsidies, and equilibrium labour market outcomes. In: Phelps ES (eds) Designing inclusion: tools to raise low-end pay and employment in private enterprise, Cambridge University Press, Cambridge, pp 44-73

Moyen S, Stähler N (2013) Unemployment insurance and the business cycle: should benefit entitlement duration react to the cycle?' Macroecon Dyn. doi:10.1017/S1365100512000478

Pissarides C (2000) Equilibrium unemployment theory, 2nd edn. MIT Press, Cambridge

Schmitt-Grohé S, Uribe M (2003) Closing small open economy models. J Int Econ 61:163-185 
Schwarzmüller T, Stähler N (2011) Reforming the labor market and improving competitiveness: an analysis for Spain using FiMod. Deutsche Bundesbank, Frankfurt am Main (discussion paper, series 1: economic studies, no. 28/2011)

Smets F, Wouters R (2003) An estimated stochastic general equilibrium model of the Euro area. J. Eur. Econ. Assoc. 1:1123-1175

Smets F, Wouters R (2007) Shocks and frictions in US business cycles: a Bayesian DSGE approach. Am. Econ. Rev. 97:586-606

Stähler N (2007) Employment protection and unemployment: a theoretical analysis evaluating recent policy proposals. Peter Lang Verlag, Frankfurt

Stähler N (2008) Unemployment and employment protection in a unionized economy with search frictions. Labour 22:271-289

Stähler N, Thomas C (2012) FiMod—a DSGE model for fiscal policy simulations. Econ Model 29:239-261

Thomas C, Zanetti F (2009) Labor market reform and price stability: an application to the Euro area. J Monet Econ 56:885-899

Zanetti F (2011) Labor market institutions and aggregate fluctuations in a search and matching model. Eur Econ Rev 55:644-658 